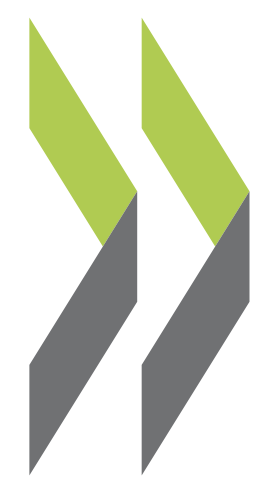

OECD Economics Department Working Papers No. 1065

\author{
Italy and the Euro Area \\ Crisis: Securing Fiscal
} Sustainability and Financial Oliver Denk Stability 
Organisation de Coopération et de Développement Économiques

Organisation for Economic Co-operation and Development

25-Jun-2013

ECONOMICS DEPARTMENT

English - Or. English

ITALY AND THE EURO AREA CRISIS: SECURING FISCAL SUSTAINABILITY AND FINANCIAL STABILITY

ECONOMICS DEPARTMENT WORKING PAPERS No. 1065

By Oliver Denk

All Economics Department Working Papers are available through OECD's Internet website at http://www.oecd.org/eco/Workingpapers

JT03342400

Complete document available on OLIS in its original format

This document and any map included herein are without prejudice to the status of or sovereignty over any territory, to the delimitation of international frontiers and boundaries and to the name of any territory, city or area. 


\section{Abstract/Résumé \\ Italy and the euro area crisis: securing fiscal sustainability and financial stability}

Italy's policy of fiscal consolidation and growth-friendly structural reforms has substantially improved its economic prospects, but the adverse sentiment that the country has faced in the sovereign bond market over the past years has deep roots. It reflects lingering anxieties over the euro area's future, as well as persistent economic and financial difficulties, in particular the high level of public debt and low potential growth. The government has rightly aimed to halt the rise in the public debt-to-GDP ratio and put it on a downward path. This could be achieved with either a balanced government budget or a small fiscal surplus. While additional fiscal tightening would have negative effects on output in the short term, it would be rewarded by faster debt reduction and lower risk of renewed financial-market reactions. In any case, the automatic stabilisers should be allowed to work.

Concerns about fiscal sustainability and the prolonged recession have spilled over to the financial sector. Lending conditions are tight, non-performing loans are high and rising, and capital has flowed out of Italy to the core countries of the euro area. The Bank of Italy should continue to ensure that banks increase provisions against losses, and strengthen their capital asset position by raising new equity from private sources, including from foreign stakeholders, by retaining earnings and by disposing of non-core assets. Resolution of the fiscal, economic and financial crisis in Italy depends in part on action at the euro area level. As a member of the euro area, Italy has benefited from the establishment of the European Stability Mechanism, the announcement by the European Central Bank of the Outright Monetary Transactions scheme and the plans for a euro-area banking union.

JEL classification: E5, E6, G2, H5, H6.

Keywords: Italy; fiscal sustainability; public debt; budget deficit; balanced-budget rule; fiscal council; pension reforms; financial stability; banking system; non-performing loans; capital ratios; loan loss provisions; TARGET2.

\section{$* * * * * * * * * * * * * * * * * * * * * * * * * * * * * * * * * * * * * * * * * * * * * * * * *$ \\ L'Italie et la crise de la zone euro : assurer la viabilité des finances publiques et la stabilité financière}

La politique d'assainissement des finances publiques de l'Italie et ses réformes structurelles porteuses de croissance ont nettement amélioré ses perspectives économiques, mais il reste que la mauvaise image du pays sur le marché de la dette souveraine, ces dernières années, a des causes profondes. Celle-ci est le signe d'inquiétudes persistantes quant à l'avenir de la zone euro et de difficultés économiques et financières qui perdurent, notamment le haut niveau de la dette publique et la faiblesse du potentiel de croissance. Le gouvernement s'est à juste titre fixé comme objectif de donner un coup d'arrêt à la hausse du ratio dette publique/PIB et de l'orienter ensuite à la baisse. Un budget public équilibré, ou bien un léger excédent budgétaire, pourraient lui permettre d'y parvenir. Un tour de vis budgétaire supplémentaire aurait certes des effets négatifs transitoires sur la production, mais il devrait être suivi d'une réduction plus rapide de la dette et d'une diminution du risque de nouvelles réactions des marchés financiers. En tous cas, il conviendra de laisser jouer les stabilisateurs automatiques.

Les inquiétudes quant à la viabilité budgétaire et à la récession qui dure ont rejailli sur le secteur financier. Les conditions de prêt sont restrictives, le stock de prêts non productifs important et en hausse tandis que les capitaux quittent l'Italie en direction des pays du cœur de la zone euro. La Banque d'Italie doit veiller à ce que les banques augmentent leur niveau de provisions pour pertes et renforcent leur position en actifs financiers en levant de nouveaux capitaux auprès de sources privées, y compris auprès d'actionnaires étrangers, en réinvestissant leurs bénéfices et en se débarrassant de leurs actifs non essentiels. La résolution de la crise budgétaire, économique et financière en Italie dépend en partie de l'action menée au niveau de la zone euro. L'Italie étant membre de la zone euro, elle a bénéficié de la création du Mécanisme européen de stabilité, de l'annonce du programme d'opérations monétaires sur titres de la Banque centrale européenne et des projets d'union bancaire de la zone euro.

Classification JEL : E5, E6, G2, H5, H6.

Mots-clés : Italie ; viabilité des finances publiques ; dette publique ; déficit budgétaire ; règle d'équilibre des finances publiques ; conseil budgétaire ; réformes des retraites ; stabilité financière ; système bancaire ; prêts non productifs ; ratios de fonds propres ; prêts dispositions pour pertes ; TARGET2.

\section{(C) OECD (2013)}

You can copy, download or print OECD content for your own use, and you can include excerpts from OECD publications, databases and multimedia products in your own documents, presentations, blogs, websites and teaching materials, provided that suitable acknowledgment of OECD as source and copyright owner is given. All requests for commercial use and translation rights should be submitted to rights@oecd.org. 


\section{TABLE OF CONTENTS}

\section{ITALY AND THE EURO AREA CRISIS: SECURING FISCAL SUSTAINABILITY AND}

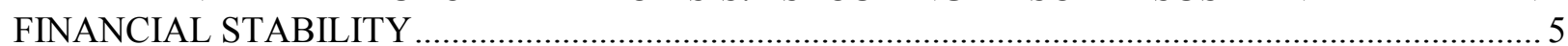

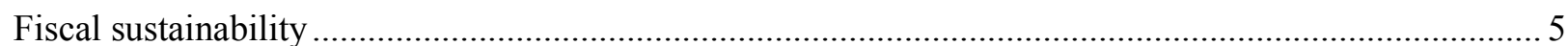

Sizeable fiscal consolidation has been achieved, largely through higher tax revenues ........................... 6

The budget deficit and public debt were worse than expected by the government ................................ 8

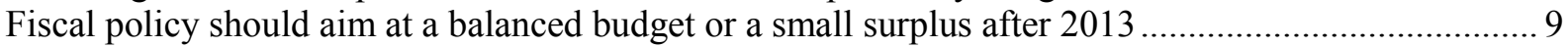

Debt redemption requirements for 2013 and 2014 are significant................................................... 11

Italy has also benefited from the ECB's announcement of the Outright Monetary Transactions

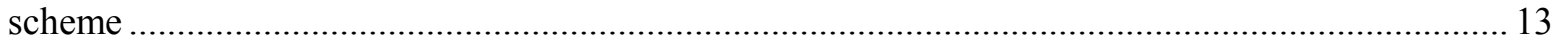

The balanced-budget rule and the fiscal council already legislated should be put into operation

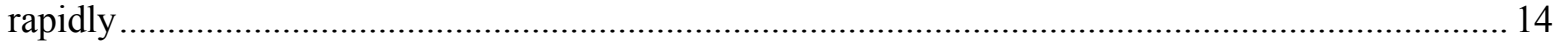

An ambitious pension reform has been introduced, but the effects will depend crucially on the labour

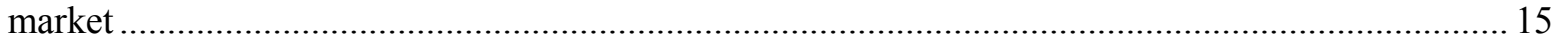

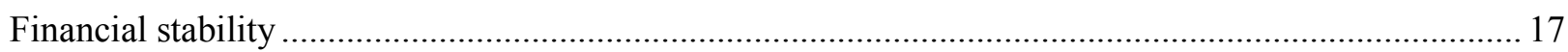

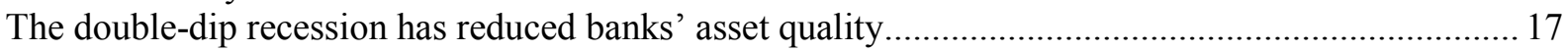

Risks of negative feedback loops between banks and public debt remain large .................................. 19

The large-scale capital flight has stalled, though not significantly reversed ...................................... 22

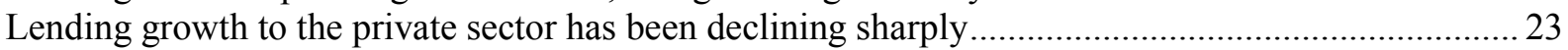

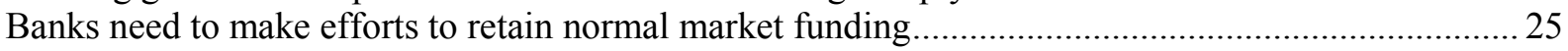

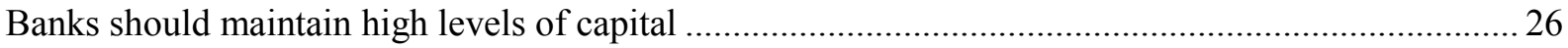

Banks should be encouraged to adopt specific corporate structures................................................... 28

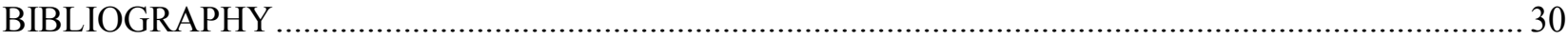

\section{Tables}

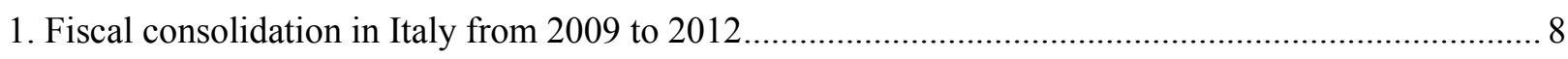

2. Revision to the fiscal plans of the government from April 2012 to April 2013 .................................. 9

\section{Figures}

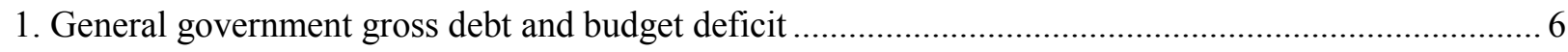

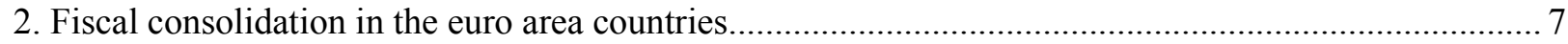

3. Long-term simulations of general government gross debt ................................................................ 10

4. Maturing marketable public debt for payment in the euro area …..................................................... 12

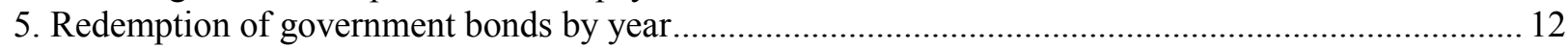

6. Average life of government debt and government debt reaching maturity in the next 12 months ....... 13

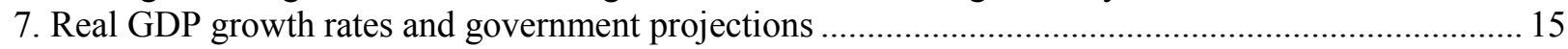

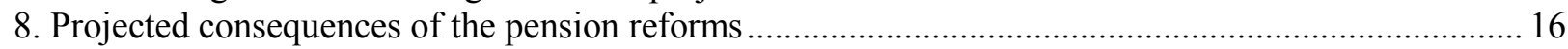

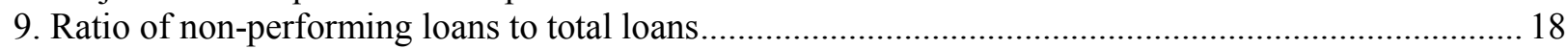

10. Credit default swaps (CDSs): Italian sovereign and Italian banks .................................................. 19

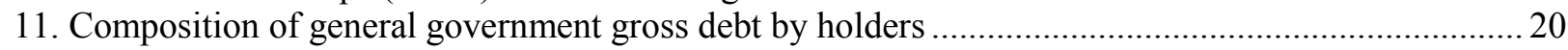

12. Capital ratio simulations for Italy's top five banking groups ........................................................ 21

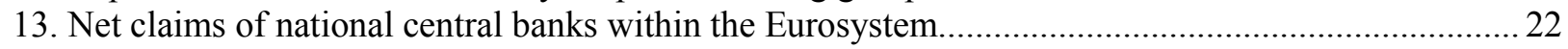

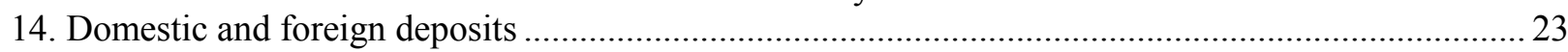

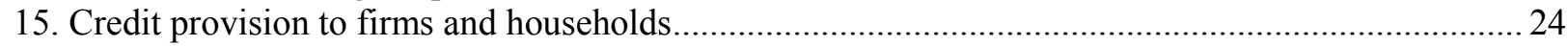


ECO/WKP(2013)51

\section{Boxes}

1. The debt swap by Banca Monte dei Paschi di Siena in mid-2012 .................................................... 26

2. Summary of recommendations to improve fiscal sustainability and financial stability ......................29

The statistical data for Israel are supplied by and under the responsibility of the relevant Israeli authorities. The use of such data by the OECD is without prejudice to the status of the Golan Heights, East Jerusalem and Israeli settlements in the West Bank under the terms of international law. 


\title{
ITALY AND THE EURO AREA CRISIS: SECURING FISCAL SUSTAINABILITY AND FINANCIAL STABILITY
}

\author{
By Oliver Denk ${ }^{1}$
}

The Italian economy is the third largest in the euro area, and its successful exit from present difficulties would be an important determinant of the single currency's future. The government's financing problems have their roots in the build-up of fiscal imbalances and persistently weak economic performance. On joining the euro area in 1997, Italy committed to lower the public debt-to-GDP ratio from some $120 \%$ to $60 \%$, but serious declines ceased in 2003 (by which time it had troughed at some 105\%; Figure 1), despite the large bonus of reduced interest payments due to euro adoption. Efforts to reduce the fiscal imbalances resumed in 2009 under the pressure of the bond market and in the framework of reinforced euro area fiscal rules. This has led to a large fiscal tightening, reflected in a declining budget deficit, and implemented in an environment of weak domestic and external demand, which has contributed to a severe double-dip recession. In 2011-12, the fragile situation of Italian banks, the ongoing pressure of the sovereign bond market and concerns about a euro-area break-up gave rise to substantial capital flight. This caused liquidity in the banking system to dry up which, together with regulatory pressure to build up equity capital, has resulted in tightening credit conditions. This paper analyses the challenges faced by Italy to secure fiscal sustainability and financial stability against the background of the financially-stressed euro area.

\section{Fiscal sustainability}

Italy's general government gross debt reached $127 \%$ of GDP in 2012, the third highest level in the OECD, behind Japan and Greece. According to the OECD Economic Outlook (OECD, 2013a), it is set to rise to some $132 \%$ in 2013 and $134 \%$ in 2014 . By contrast, the general government budget deficit, which fell to $2.9 \%$ of GDP in 2012, is comparatively low and on a declining trend so far. It is projected to slightly increase to $3.0 \%$ in 2013, before resuming its improvement to 2.3\% in 2014 (OECD, 2013a). Nevertheless, since national accounts figures for GDP include an estimate for the relatively large tax-evading informal economy, measures of fiscal sustainability based on the debt- and deficit-to-GDP ratios somewhat understate Italy's fiscal challenge relative to other countries, where the size of GDP reflects the capacity to tax a larger part of the economy.

1. Economics Department, OECD. Email: Oliver.Denk@oecd.org. This paper was originally produced for the 2013 OECD Economic Survey of Italy and published in May 2013 under the authority of the Economic and Development Review Committee (EDRC) of the OECD. Compared to the Survey, updates of data and policy developments are incorporated where relevant. The paper has benefited from helpful contributions by Patrick Lenain and Sebastian Schich. Andrew Dean, Robert Ford, Paul O’Brien, Pier Carlo Padoan, Italian Banking Association representatives, Bank of Italy staff and Italian government officials provided useful comments and suggestions. Special thanks are due to Josette Rabesona and Ane Kathrine Christensen for valuable statistical support. 
Figure 1. General government gross debt and budget deficit

As a percentage of GDP

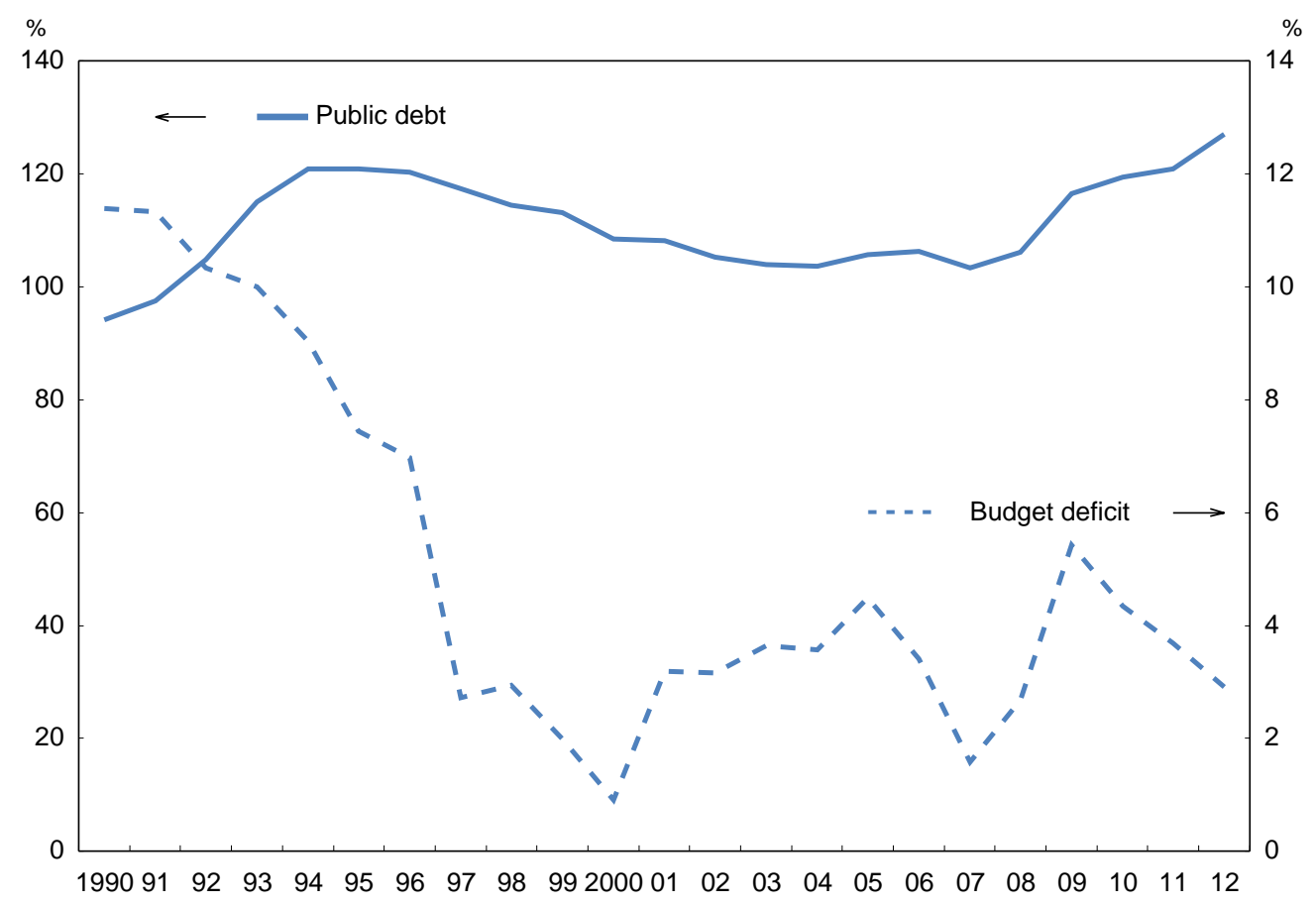

Source: OECD Economic Outlook database.

\section{Sizeable fiscal consolidation has been achieved, largely through higher tax revenues}

Sizeable fiscal consolidation, as measured by the change in the structural (or cyclically-adjusted) budget balance, was achieved during the period 2009-12. The total consolidation is estimated to have been $3.2 \%$ of potential GDP (OECD, 2013a), the largest part of it (2.2\%) in 2012. This is substantial and about the same as in the euro area as a whole (Figure 2), although considerably less than in the other troubled peripheral economies - Greece (improvement of 15.7\%), Spain (5.2\%), Ireland (4.6\%), Portugal (4.3\%) where in 2009 fiscal deficits and, correspondingly, fiscal consolidation needs were larger. Because GDP growth has been below potential since 2009, there has been less progress in reducing the headline deficit (improvement of $2.5 \%$ ) than in reducing the structural deficit. The pro-cyclical fiscal tightening has had significant effects on output and large social costs, reflected in higher unemployment and lower incomes. But it was necessary to reduce the risk of further rises in spreads, which could have led to even less growth and higher deficit and debt (Égert, 2010; Laubach, 2009). 
ECO/WKP(2013)51

Figure 2. Fiscal consolidation in the euro area countries

Change in the structural balance (\% of potential GDP), 2009 to 2012

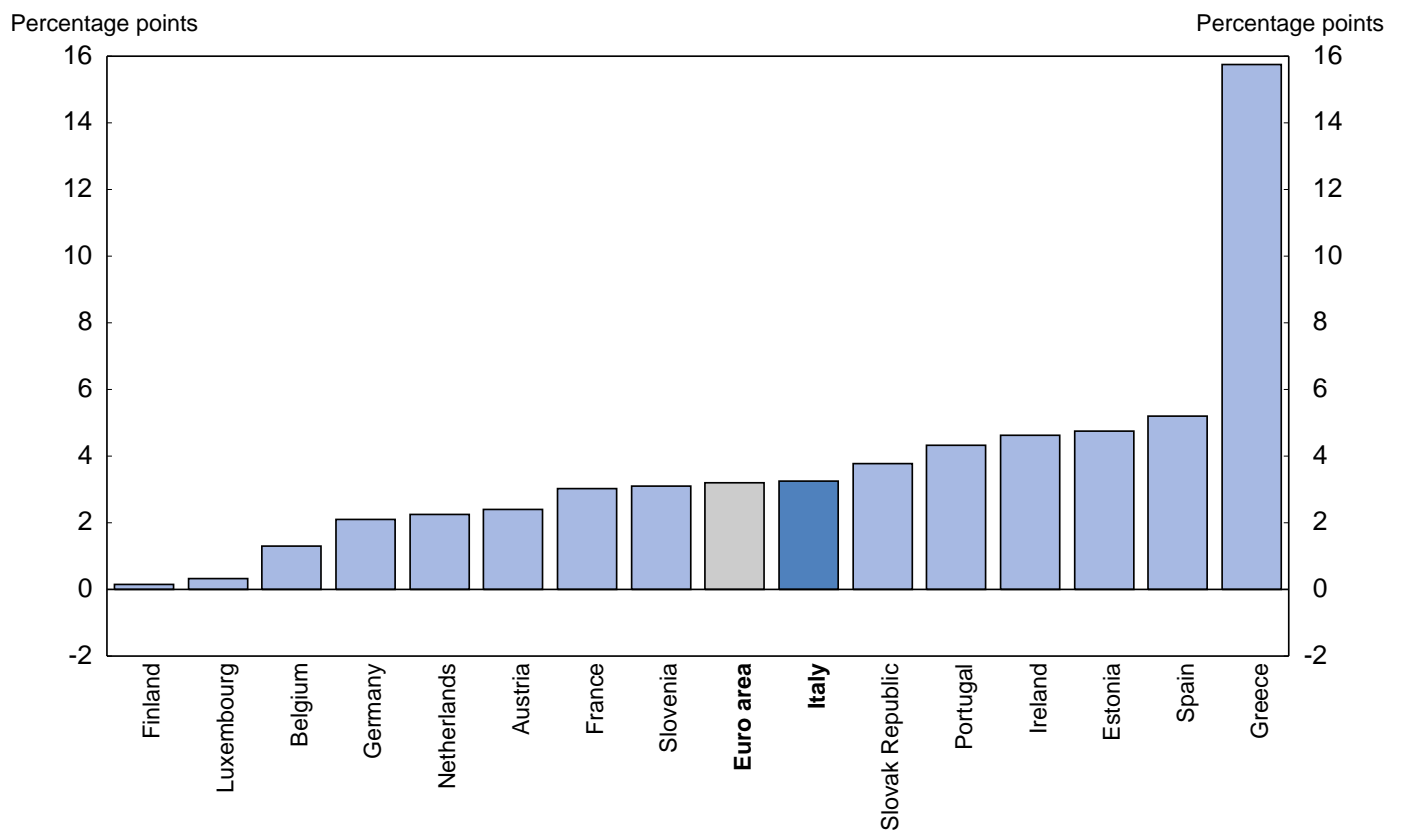

Note: Euro area is the weighted average of the euro area countries shown. The 2009 values are from 2008 for Estonia and 2010 for Finland, Germany, Luxembourg, the Slovak Republic and Slovenia, as in those years the structural deficit reached its maximum.

Source: OECD Economic Outlook database.

Over the past three years, rising tax revenues and other receipts accounted for $75 \%$ (or $2.4 \%$ of potential GDP) of the fiscal consolidation (Table 1), and lower spending only $25 \%$ (or $0.9 \%$ of potential GDP). Abstracting from the increase in interest expenditure, which partly was a result of the rise in spreads, the contribution of revenues to fiscal consolidation was about three fifths. Cyclically-adjusted revenues rose on account of increased taxes on production and imports (which mainly consist of the valueadded tax and other taxes on production) and direct taxes on households, whereas those from social security contributions and direct taxes on businesses remained approximately constant.

The most important consolidation measures in 2012, as planned by the government, were: revenue increases through the municipal property tax IMU (EUR 11 billion), higher excise taxes on fuels (EUR 6 billion), the reduction of tax relief (EUR 4 billion), and increasing the VAT rate from $20 \%$ to $21 \%$ (EUR 4 billion); expenditure cuts by ministries (EUR 6 billion), the ISPE (Structural Economic Policy Programmes) Fund (EUR 5 billion), and the Domestic Stability Pact governing local government spending (EUR 7 billion). These numbers are the planned savings relative to what revenue/spending would have been in 2012 with no policy change. 
Table 1. Fiscal consolidation in Italy from 2009 to 2012

\begin{tabular}{|c|c|c|c|}
\hline Cyclically-adjusted, \% of potential GDP & 2009 & 2012 & Consolidation \\
\hline Revenues: & 45.4 & 47.8 & +2.4 \\
\hline Current revenues: & 45.0 & 47.3 & +2.3 \\
\hline Taxes on production and imports & 13.6 & 14.9 & +1.3 \\
\hline Social security contributions & 13.9 & 13.8 & -0.2 \\
\hline Direct taxes on households & 11.8 & 13.0 & +1.1 \\
\hline Direct taxes on businesses & 2.5 & 2.4 & -0.1 \\
\hline Property income & 0.5 & 0.4 & -0.0 \\
\hline Other current revenues & 2.7 & 2.8 & +0.1 \\
\hline Capital revenues & 0.4 & 0.5 & +0.1 \\
\hline Expenditures: & 49.3 & 48.4 & +0.9 \\
\hline Current expenditures: & 47.4 & 47.2 & +0.2 \\
\hline Current expenditures excluding interest & 43.0 & 42.0 & +0.9 \\
\hline Interest & 4.4 & 5.2 & -0.8 \\
\hline Capital expenditures & 1.9 & 1.2 & +0.7 \\
\hline Structural balance & -3.8 & -0.6 & +3.2 \\
\hline
\end{tabular}

Note: Entries in the column "Consolidation" are positive when the item reduces the structural deficit. This means, in particular, that expenditure reductions enter positively.

Source: OECD Economic Outlook database.

\section{The budget deficit and public debt were worse than expected by the government}

The Update of the Economic and Financial Document (DEF) in September 2012 provided for fiscal consolidation (i.e. an improvement in the structural balance) of $2.8 \%$ of potential GDP in 2012 and $0.9 \%$ in 2013 , but a small fiscal expansion of $0.3 \%$ in 2014. These estimates for the structural balance are based on methodologies agreed at the European level. The plan was to reduce the headline fiscal deficit to $1.5 \%$ of GDP in 2014. This fiscal projection represented a substantial revision to the plans adopted in April 2012, and the April 2013 DEF shows further revisions (Table 2). The changes are mostly due to the worse outlook for activity, primarily a result of the distress in financial and credit markets which the government had not included in its earlier baseline projections. The government also somewhat delayed the planned fiscal consolidation, though still planning to reach structural balance in 2013 with a further improvement in 2014.

The fiscal projection for 2012 made in September (in the DEF Update) was somewhat optimistic, as data during the year showed only a modest improvement in the deficit-to-GDP ratio. A concentration of receipts at the end of the year improved the situation but the outturn, a deficit of $3.0 \%$ of GDP, fell short of the revised objective. In reporting on public accounts developments during 2012, the government focused on the state sector cash balance. This figure does not fully capture fiscal developments at the level of subnational governments and, unlike the national accounts, is not accruals-based. On the other hand, the state sector cash balance includes payments to the European Stability Mechanism (ESM), which are not included in the EU definition of the government balance. To facilitate the interpretation of public finance developments during the year, the government should report measures whose definitions are comparable to the end-year target for general government net lending. 
ECO/WKP(2013)51

Table 2. Revision to the fiscal plans of the government from April 2012 to April 2013

\begin{tabular}{l|cccc}
\hline & 2011 & 2012 & 2013 & 2014 \\
\hline Headline fiscal balance & -3.8 & $-1.7 \rightarrow-3.0$ & $-0.5 \rightarrow-2.9$ & $-0.1 \rightarrow-1.8$ \\
Structural fiscal balance & -3.5 & $-0.4 \rightarrow-1.2$ & $+0.6 \rightarrow 0.0$ & $+0.6 \rightarrow+0.4$ \\
Gross public debt & 120.8 & $123.4 \rightarrow 127.0$ & $121.5 \rightarrow 130.4$ & $118.2 \rightarrow 129.0$ \\
Memo: Real GDP growth & +0.4 & $-1.2 \rightarrow-2.4$ & $+0.5 \rightarrow-1.3$ & $+1.0 \rightarrow+1.3$ \\
\hline
\end{tabular}

Note: Headline fiscal balance, structural fiscal balance and gross public debt refer to general government, measured relative to (potential) GDP. The first number in each cell refers to the government's plan in April 2012 and the second to its revised plan in April 2013. Gross public debt includes loans to Greece and Italy's share in the EFSF/ESM. The figures for 2011 are from April 2013 , and hence incorporate small data revisions compared to April 2012.

Source: Economic and Financial Document, April 2012 and April 2013.

\section{Fiscal policy should aim at a balanced budget or a small surplus after 2013}

In May 2013, the European Council abrogated the Excessive Deficit Procedure for Italy, based on the 2012 headline deficit and the corresponding projections for 2013 and 2014 not exceeding 3\% of GDP. The government's objective is to reduce the structural deficit by about $1 \%$ of potential GDP in 2013, which under its projections would balance the general government deficit in structural terms, in line with euro area requirements. This fiscal consolidation is appropriate. Thereafter, the government aims to stay close to structural balance. The plan announced in April 2013 to significantly reduce government arrears to companies is welcome. The impact on growth is uncertain, a conservative estimate (GDP growth uplift of 0.2 and 0.3 percentage points in 2013 and 2014 respectively) is included in OECD (2013a). As well, after the publication of the DEF the grand-coalition government has indicated its intent to revise the property tax on primary residences. Under the macroeconomic projection of the OECD, which assumes the government implements the envisaged path for the changes in the structural balance of the DEF from April 2013, the headline deficit falls only slightly and debt would continue to rise through 2014.

According to simulations based on a model similar to Lenain et al. (2010) and on potential growth projections from the Long-Term Baseline database (OECD, 2013a), introducing and maintaining measures to attain a structural budget surplus of $2 \%$ of potential GDP by 2017 would reduce the debt-to-GDP ratio to the Maastricht ceiling of $60 \%$ of GDP by 2030 (Figure 3, Panel A). This supposes a fiscal multiplier of unity ( 0.7 in the year of fiscal consolidation, and 0.3 in the following), and a closing of the (negative) output gap by $20 \%$ each year. To reach the assumed structural surplus of $2 \%$ of GDP, fiscal consolidation from 2013 onwards would need to be of an amount close to that achieved during 2009-12, when the initial structural deficit was some $4 \%$ of potential GDP. By contrast, the government's longer-term plan to maintain a balanced structural budget would leave debt in 2030 at $78 \%$ of GDP and reduce it to $60 \%$ of GDP in 2037. Reversing the public debt trend and putting it on a downward trajectory could thus be achieved either with a balanced budget or a small fiscal surplus. Given the high level of debt, even a small fiscal relaxation would be a risky strategy.

Continued fiscal consolidation would be politically difficult and have transitory negative effects on output, especially in the current environment of simultaneous deleveraging in many OECD countries and limited scope for offsetting monetary policy reactions. It would, however, be rewarded by faster debt reduction and a lower risk of renewed financial-market turbulence and a "bad equilibrium" (e.g. Corsetti et al., 2013; Padoan et al., 2012). The likelihood of such a "bad equilibrium", characterised by negative feedbacks between high sovereign risk premia, falling economic activity and low confidence, tends to increase with the level of public debt. A speed of debt reversal (of approximately 5\% of GDP annually) similar to that implied by a structural surplus of $2 \%$ of potential GDP has previously been achieved by several OECD countries, including Canada (1997-2000), Spain (1985-1990), and Belgium 
(1994-2007). If macroeconomic conditions deteriorate once again, automatic stabilisers should be allowed to work.

Figure 3. Long-term simulations of general government gross debt

As a percentage of GDP
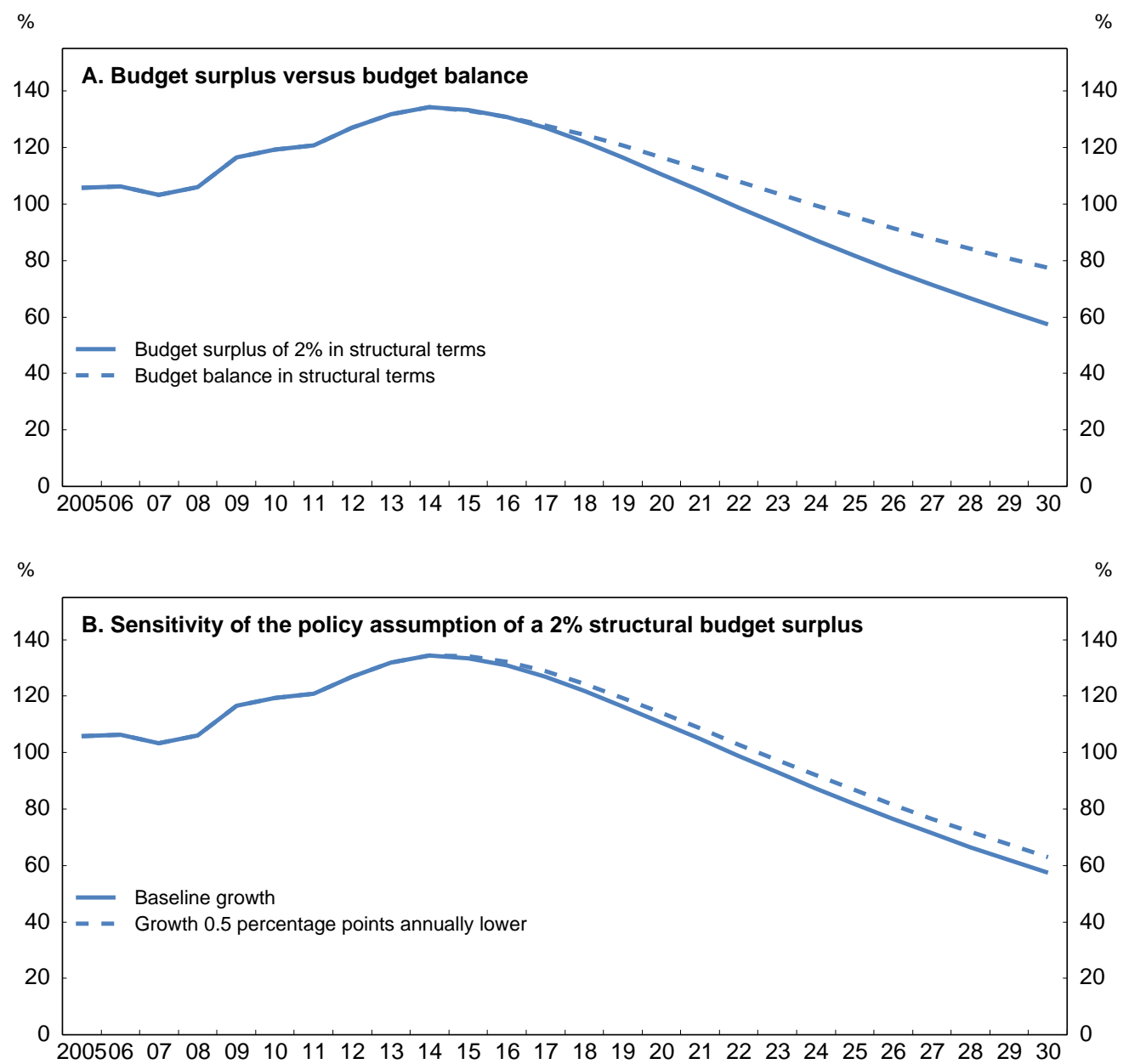

Note: The solid curve in Panel A shows the evolution of general government gross debt assuming the government gradually phases in a budget surplus of $2 \%$ of potential GDP in structural (or cyclically-adjusted) terms by 2017 and then maintains it at this level. The broken curve depicts its evolution assuming the government follows its fiscal plans in the DEF from April 2013 and maintains a balanced budget in structural terms from 2017 onwards. The solid curve in Panel B is the same as the solid curve in Panel A. The broken curve depicts the evolution of general government gross debt assuming the same changes to the structural balance but with the annual real GDP growth rate being 0.5 percentage points lower. All simulations suppose a fiscal multiplier of unity $(0.7$ in the year of fiscal consolidation, and 0.3 in the following), and a closing of the (negative) output gap by $20 \%$ each year.

Source: Lenain et al. (2010), OECD Economic Outlook database and OECD Long-Term Baseline database.

The benchmark simulations assume that the level of real GDP gradually converges to potential output, whose annual growth rate rises to $2.1 \%$ in 2030 , more than two percentage points up from the current $-0.4 \%$. There are downside risks to these assumptions. The global financial crisis may have significantly reduced the level of potential output. Or the euro area crisis could intensify further and lead to subdued growth for a prolonged period. Long-lasting hysteresis effects could arise from today's high unemployment. The policy assumption of a $2 \%$ structural budget surplus is, however, relatively robust to real GDP growing 0.5 percentage points below the baseline, which would bring the debt-to-GDP ratio to $63 \%$ by 2030 and $60 \%$ in 2031 (Figure 3, Panel B). 
Contrary to the consolidation thus far, future policy should, however, place more emphasis on spending control rather than tax increases, because of the already high level of taxation and empirical evidence (e.g. Mertens and Ravn, 2013; Alesina et al., 2013), though not entirely conclusive, of less harmful effects on output. Spending cuts should be selective, and policy measures need to raise value-formoney. Although state budget expenditure data showed no decline in 2012 relative to 2011, the government legislated several measures with the objective to exert some downward pressure on spending in future years, which on its projection would help rebalance the composition of fiscal consolidation undertaken so far. In July 2012, parliament adopted a law (the "spending review") with savings estimated at EUR 10.8 billion in 2013, EUR 11.6 billion in 2014, and EUR 12.1 billion in 2015 (for more details see OECD, 2013b). The recent budget law requires setting aside any extra savings coming from lower-thanprojected interest payments. Over the medium term, temporary annual savings stemming from the pension reform approved in December 2011 will materialise. The government projects them to amount to EUR 7.6 billion in 2014, increasing to almost EUR 22 billion in 2020, before declining to near zero in 2040 .

\section{Debt redemption requirements for 2013 and 2014 are significant}

Italy will have the largest nominal amount of maturing marketable public debt among euro area countries by the end of 2014, exceeding both France and Germany (Figure 4). This reflects the large absolute size of its public debt and a relatively high share of marketable debt in total public debt. The redemption requirements for government bonds (debt instruments with maturity of more than one year) have been EUR 159 billion in 2013. A significant amount of current debt is also due for redemption in each of the following two years (Figure 5). Actual refunding needs in future years will be higher than shown in the chart, as debt rolled over each year itself has to be refunded in the future. In addition, in 2013 EUR 151 billion of Treasury bills (debt instruments with maturity of up to one year) will have fallen due at least once. The total redemption requirements of bonds and bills in 2013 as of 1 January 2013 worth some EUR 310 billion have been of broadly similar magnitude as in previous years (Figure 6); compared to 2012, for example, they are EUR 23 billion less. 
Figure 4. Maturing marketable public debt for payment in the euro area

\section{April 2013 - 31 December 2014}

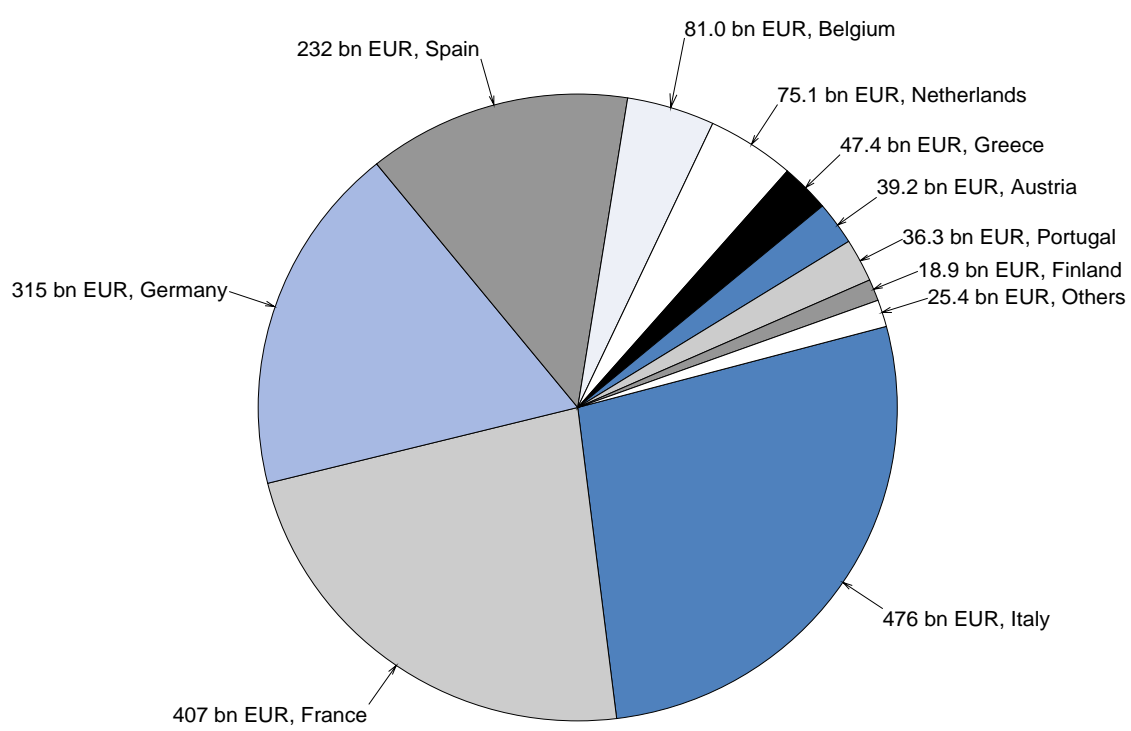

Note: Others include Ireland, the Slovak Republic, Slovenia, Luxembourg and Estonia. The definition of these numbers is different to that of those mentioned in the text from the Ministry of Economy and Finance, partly because this source only includes marketable public debt.

Source: Bloomberg.

Figure 5. Redemption of government bonds by year

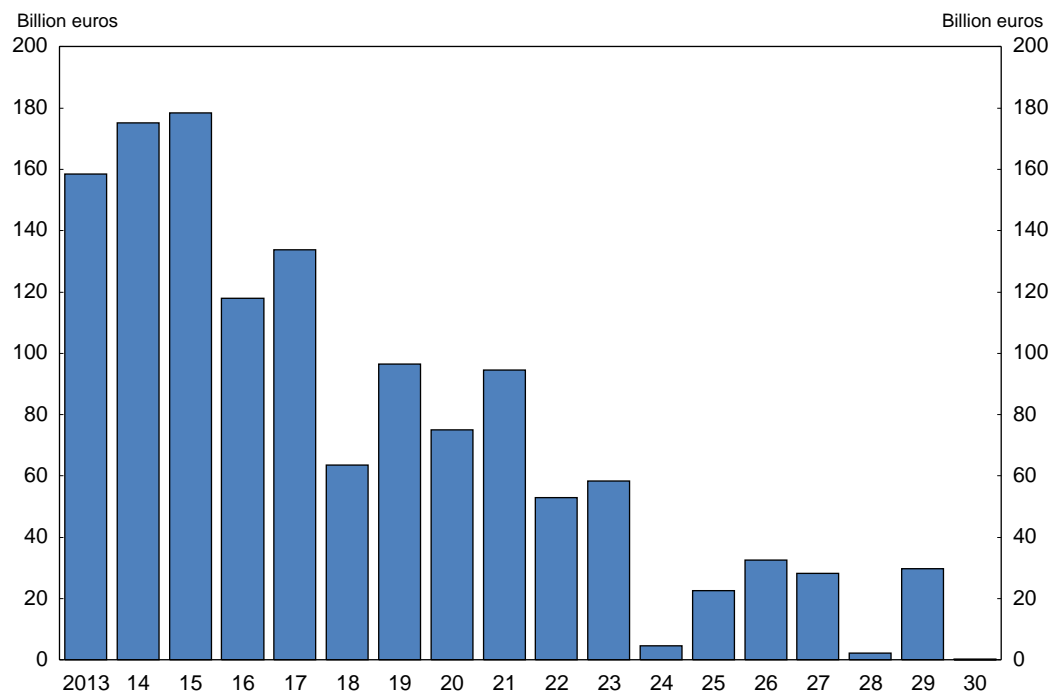

Note: Government bonds only include debt instruments with maturity of more than one year. In addition to the figures shown here, in every year, approximately EUR 150 billion of Treasury bills, debt instruments with maturity of up to one year, fall due. Actual refunding needs in 2014, etc. will be higher than indicated in the chart, as debt rolled over each year itself has to be refunded in the future.

Source: Ministry of Economy and Finance. 
The pass-through of the higher interest rates paid on new debt over the last 24 months on the fiscal balance is mitigated by the relatively high average maturity of government debt of $6 \frac{1}{2}$ years. Also, with the rise in interest rates more pronounced at the long end of the yield curve, the government has increasingly issued short-term securities. This has contained interest spending, but also had the consequence of reducing the average maturity of government debt somewhat, after a long period during which it rose (Figure 6). The authorities saw this reduction as a tactical move allowed for by the previous lengthening of the maturity structure. Demand has held up so far. In October 2012, the government raised EUR 18 billion through the issue of a 4-year inflation-linked bond primarily aimed at domestic retail investors, the largest amount ever sold in a single debt offering in Europe. In general, the investor base has increasingly shifted to domestic sources (more details on this below). Debt management should continue to seek to maintain debt at different levels of maturity and offer debt instruments attracting a broad set of investors.

Figure 6. Average life of government debt and government debt reaching maturity in the next 12 months

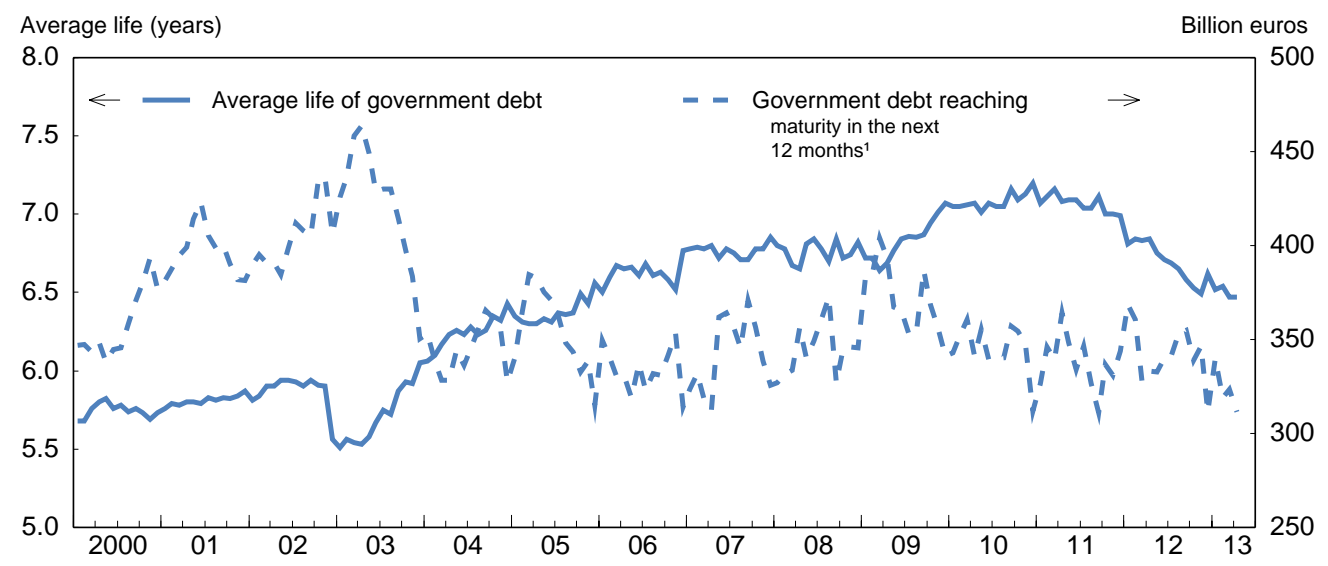

1. Adjusted by harmonised consumer price index. Data are based on the last observation.

Source: Ministry of Economy and Finance and OECD Economic Outlook database.

\section{Italy has also benefited from the ECB's announcement of the Outright Monetary Transactions scheme}

Interest rates on government bonds increased significantly during the second half of 2011 (with those on 10-year bonds at times exceeding 7\%), although they declined during 2012 and 2013 as government fiscal policy and structural policy reforms, along with action at the European level, reassured markets. Very accommodative monetary policy in other advanced OECD economies and Italy's rising current account balance may have played a role, too, for the continued improvement in market confidence, despite the initially inconclusive general election in February 2013. Yields on 10-year bonds in May 2013 fluctuated around $4 \%$, while the German equivalent rates were about $1 \frac{1 / 4-1 / 2}{2}$ per cent. Hence, to obtain over the next 10 years the same return on German bonds as on Italian bonds, investors were willing to pay some $20-25 \%$ more for the German bond. Although the large public debt and low growth expectations are probably important explanatory factors, spreads have departed substantially from conventional calculations of their fundamental value. Regression estimates (IMF, 2012) suggest that the health of the banking sector and euro area market fragmentation, proxied by the accumulation of cross-border TARGET2 liabilities (more details on this below), have given rise to excess risk premia. Di Cesare et al. (2012) argue that the spread of Italy's 10-year interest rates with Germany that is consistent with the state of the economy would be around 2\% rather than the 21/2-23/4 per cent observed in May 2013.

Spreads fell significantly after the announcement by Mario Draghi, the President of the European Central Bank (ECB), in July 2012 to do "whatever it takes" to save the euro, which was followed by the 
ECB's introduction of the Outright Monetary Transactions (OMT) scheme on 6 September 2012. The ECB may conduct OMTs (purchases of sovereign debt with up to three years of maturity in the secondary market) for countries under a macroeconomic adjustment or a precautionary programme with the ESM. The objective is to help lower policy rates be transmitted to borrowing costs in peripheral countries. The Italian authorities have not indicated that they would seek European financial assistance, since they remain able to attract funding from the sovereign bond markets under terms consistent with a sustainable debt path.

\section{The balanced-budget rule and the fiscal council already legislated should be put into operation rapidly}

In April 2012, parliament approved a constitutional amendment that introduces a balanced-budget provision. It will require the government to achieve structural budget balance, i.e. general government net borrowing will be permitted only in cyclical downturns (with surpluses in upturns), or exceptional circumstances. Sub-national governments will be subject to a new balanced-budget requirement, too, but this will be defined in nominal terms, i.e. with no adjustment for the economic cycle. The constitutional amendment, which is consistent with the budgetary framework of the European Union, will become effective as of the fiscal year 2014. The secondary legislation of December 2012 determined, inter alia, the definition of exceptional circumstances (i.e. severe economic recessions and natural disasters) and the setting of the maximum cumulated deviation in structural terms beyond which corrections are required (i.e. more than $0.5 \%$ of potential GDP from the medium-term objective). The reform also establishes an independent body, within parliament, responsible for monitoring public finances and compliance with the fiscal rules.

The fiscal rule and the fiscal council are welcome innovations, which should be implemented in full, and with the objective of maintaining a prudent approach to long-term fiscal challenges. They are suitable institutional mechanisms to support fiscal discipline and credibility of debt reduction (IMF, 2009; Hagemann, 2010). By anticipating their role as a commitment device, both could have positive impacts on financial markets even in the short term. For this effect to be lasting, the government will have to put them into operation rapidly. The new law also introduces a debt rule, consistent with the "Six-Pack" decision of the European Union, which requires annual reductions in the debt-to-GDP ratio by $5 \%$ of the difference between the level of debt and the $60 \%$ reference level, measured over a 3-year average. The newlyestablished balanced-budget rule and fiscal framework need to be implemented with transparent data and methodology to allow effective monitoring of compliance.

The fiscal council is charged with assessing the underlying assumptions of fiscal projections, including the macroeconomic projections. Since the establishment of the euro, the projections by the government in the Stability Programme for real GDP growth in the following year have been broadly in line with an average of other forecasters (Figure 7). Yet, they overestimated actual GDP growth in 10 out of 14 years; the average and median of the projection error has been an overestimation of 1.1 percentage points. Ensuring that the assessments of the fiscal council are an informative counterpart to official macroeconomic and fiscal projections and plans could help improve their accuracy. To this end, the fiscal council will need to be strongly independent, with well-qualified staff, perhaps including non-Italian members, be adequately funded, and be given the prerogative to investigate any issues it considers relevant to fiscal sustainability. It should be guaranteed access to whatever data it feels it needs to carry out its analyses. 
Figure 7. Real GDP growth rates and government projections

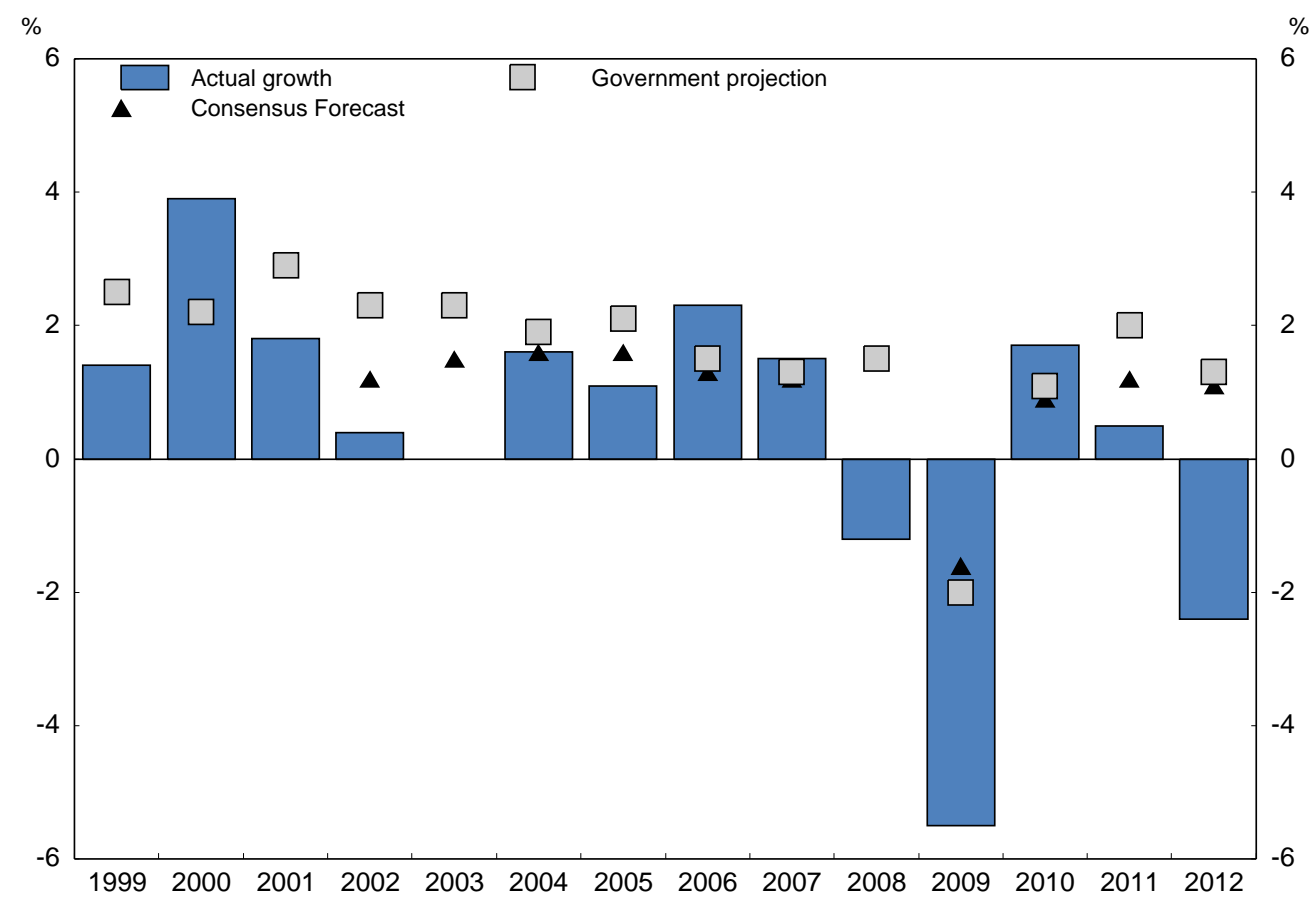

Note: Government projections are from the Stability Programme of the preceding year. Consensus Forecast projections are as near as possible from the same month as the Stability Programme.

Source: Ministry of Economy and Finance, ISTAT and Consensus Forecast.

\section{An ambitious pension reform has been introduced, but the effects will depend crucially on the labour market}

Public pension expenditure in 2010 was $15 \%$ of GDP, exceeding that of any other country in the OECD (OECD, 2012a). Successive governments, in a series of reforms beginning in 1992, have worked to avoid a cost explosion in the long term. The pension system now provides a flexible framework for retirement decisions, with actuarial neutrality at the margin; pensions are related to the actuarial value of contributions and the pension age is linked to life expectancy. OECD (2013b) summarises some of the most recent adjustments. These reforms have helped stabilise the projected level of pension expenditure relative to GDP. Following measures in 2011 with estimated savings of up to $1 \%$ a year during 2020-30, the government projects it to stay below $17 \%$ of GDP through the next 50 years, although it will remain high in international comparison. Over the next decade, the main savings will come from a higher retirement age. The average effective exit age from the labour market is assumed to rise from 61 in 2010 to 65 in 2020, a much more rapid increase than in any other country of the European Union (Figure 8, Panel A; European Commission, 2012). This would have profound implications for the labour market: by 2020 the participation rate of the 55-64-year-olds is assumed to rise to $57 \%$, a considerable increase relative to the $38 \%$ participation rate in 2010 (Figure 8, Panel B). The resulting rise in labour supply should have a significant positive impact on potential output in the long run.

The overall impact of the pension reforms will therefore crucially rest on the ability of the labour market to successfully absorb the increase in labour supply into productive employment, particularly over the next 5-10 years. Reliable statistics on age-productivity profiles are scarce, but the productivity of many older workers is likely to be declining between ages 50-65, precisely those for whom employment rates 
need to rise for the pension reform to be successful. A key issue, then, is whether the labour market is flexible enough to generate wage declines as people extend their working lives. This may be a particularly salient problem in Italy, where the education of workers around age 50 is much lower than that of younger cohorts. In the public sector, for example, wages, together with responsibilities, often increase with seniority; hence a higher retirement age, with no increase in the flexibility of the current wage system, could lead to the government paying workers more than their productivity would justify. Greater use of training policies (OECD, 2011), in the context of a more general move to a more inclusive "flexicurity" system of the labour market (see also OECD, 2013b), and remuneration policies encouraging the alignment of wages with productivity developments through the lifecycle would help underpin the large rise in the employment of older workers that is currently projected. The authorities are aware of these challenges (which also face most countries with ageing populations) and have taken some steps, but further sustained measures will be necessary.

Figure 8. Projected consequences of the pension reforms
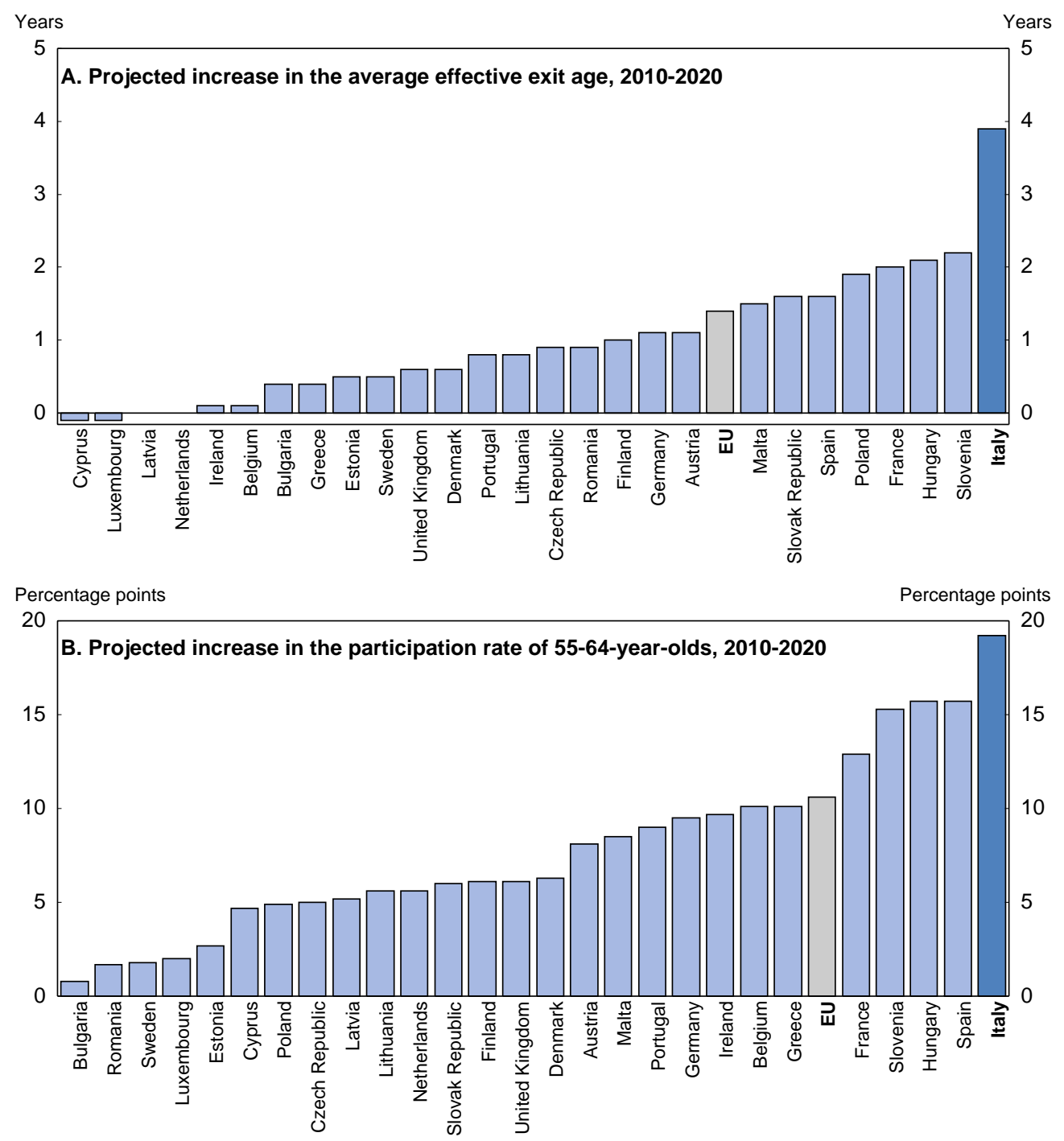

Note: EU27 is the weighted average of all countries.

Source: European Commission (2012). 


\section{Financial stability}

The financial sector had weathered the initial phase of the global financial crisis in 2008-09 comparatively well with the banks, for instance, receiving no large-scale equity support from the government. However, over the past 24 months the banking system has come under increasing stress. Causality has mainly run from fiscal imbalances and the prolonged recession to financial sector problems, contrary to some other countries in difficulty. Granger causality tests by the Italian Banking Association over the sample period from January 2006 to June 2010 indicate that in Italy sovereign risk caused banking risk, while banking risk did not cause sovereign risk, different to some other euro area countries. Although low interest rates in the 2000s fuelled significant credit expansion, there were no extreme excesses, as was the case for the property markets in Ireland and Spain, for example.

Main catalysts for the increased fragility of Italy's financial sector have been the weakening of real activity, the deterioration of the sovereign debt and the risk of a euro-area break-up. The recession has led to a rise in credit losses and a fall in corporate profits, damaging banks' balance sheets. Banks have been caught up in a negative feedback loop with the sovereign and have faced funding pressures amid increased market fragmentation in the euro area. Foreigners have shed investments and deposits in Italy. Reflecting these developments, rating agencies downgraded many Italian banks, including large and medium-sized banks. For example, Standard \& Poor's downgraded 15 Italian banks in early August 2012, several to junk status. Also reflecting these developments, for the past two years the share prices of Italian banks have underperformed relative to those of a broad group of their European peers.

\section{The double-dip recession has reduced banks' asset quality}

Two recessions within four years have reduced the asset quality of the banks. The share of nonperforming loans in total loans has risen to 13\%, a high level in OECD comparison (Figure 9). Although in some cases the definition for impaired loan classification is not entirely standardised across countries, possibly exaggerating the stock of impaired loans in Italy, this is less relevant for the measurement of new impaired loans, which are also high and rising. Corporate balance sheets have suffered from the decline in profitability to a 20 -year low, and financial expenses now absorb more than $20 \%$ of internally-generated resources. Banks' profits are also under pressure from the real estate market, particularly through their exposure to loans to construction firms. Over the five years to end-2012, the number of house sales more than halved, and investment in residential construction declined by almost $20 \%$. The re-introduction of a municipal real estate tax on the primary residence in 2012, an important component in the government's strategy for budget consolidation, likely contributed to the depressed housing market. 
Figure 9. Ratio of non-performing loans to total loans

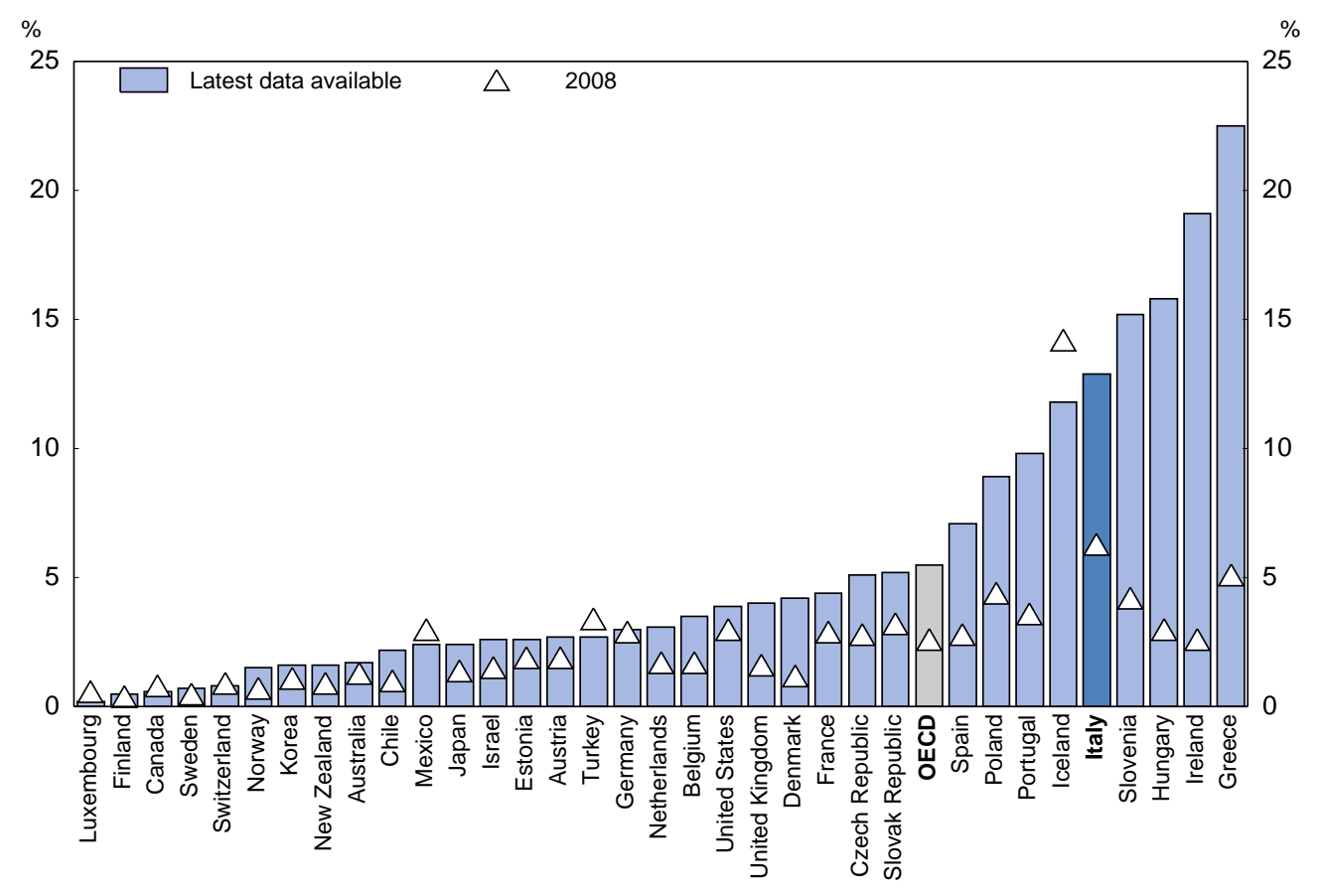

Note: OECD area is the simple average. The 2008 value is from 2009 for Iceland. The definition for impaired loan classification is not entirely standardised across countries, possibly exaggerating the stock of impaired loans in some, including Italy, relative to others.

Source: IMF, Financial Soundness Indicators database.

Indebtedness of the private sector is low in Italy compared with other OECD economies, although its rate of growth since the pre-boom years in 2000 has been relatively high (OECD, 2012b). Non-financial corporations' gross debt-to-GDP ratio (on a consolidated basis) in late 2011 was $93 \%$ (up from $67 \%$ in $2000)$, just below the euro area average of $97 \%$ (79\% in 2000). Similarly, households' gross-debt-todisposable income ratio (on a consolidated basis) grew more in Italy than in the euro area as a whole, reaching $80 \%$ in late 2011 (up from $45 \%$ in 2000), below the euro area average of $108 \%(85 \%$ in 2000 ). Contrary to some other OECD countries, such as the United States and the United Kingdom, leverage of the private sector has continued to rise since the beginning of the crisis in 2007. The developments of these simple indicators suggest that Italy's financial sector, while traditionally careful in its lending practices, engaged in some significant credit expansion in the run-up to the global financial crisis, which increased its risk exposure, and has not drawn back since then.

Banks have increased their provisions for credit risk, but coverage ratios (the stock of provisions over the total amount of impaired loans) have nonetheless declined. As a consequence, the Bank of Italy (the national financial supervisor) has been intensifying its assessment of the adequacy of provisions, taking into account both aggregate variables (system-wide averages, the outlook for the real economy) and individual variables (composition of loan portfolio, collateral, accounting practices, etc.), and is requiring banks with inadequate coverage ratios to take prompt corrective measures (Bank of Italy, 2013a). These actions are welcome, and the Bank of Italy must continue to ensure that banks increase their provisions against losses and coverage ratios.

Supervisors need to encourage banks to recognise losses as they occur and to develop strategies for the sale, restructuring or write-down of impaired loans. This should support the deleveraging process in the 
non-financial private sector and force the financial sector to raise new capital some of which would be available for new lending. It might also stimulate economic activity by redistributing losses from debtors with a high propensity to consume to creditors with a lower propensity. Stronger supervisory action may be necessary. The Bank of Italy's inspections have revealed that banks misclassify the status of about $20 \%$ of examined loans. Although these $20 \%$ include misclassification within the non-performing category and the pool of examined loans is biased towards those more problematic, this is still a large number. The large stock of non-performing loans is a result also of the long processing times in the legal system for loan write-downs. Speeding up foreclosure procedures should thus be an important objective of judicial reform (see also OECD, 2013b).

\section{Risks of negative feedback loops between banks and public debt remain large}

The sustainability of the public finances and health of the banking system are highly interdependent. The substantial deterioration in the assessment of the quality of Italian government debt since the beginning of the euro area crisis has sharply affected the market assessment of the value of banking sector debt. Credit default swap premiums for the Italian sovereign and the three biggest banks - UniCredit, Intesa Sanpaolo, Banca Monte dei Paschi di Siena - have exhibited strong co-movements (Figure 10). The weak situation of the public finances has resulted in increasing banks' exposure to mark-to-market losses on their holdings of government debt, reductions in the value of banks' collateral, credit rating downgrades of banks, and declines in the value of banks' state guarantees. At the same time, financial sector stress has increased the potential liabilities of the government.

Figure 10. Credit default swaps ${ }^{1}$ (CDSs): Italian sovereign and Italian banks

Last observation: 22 May 2013

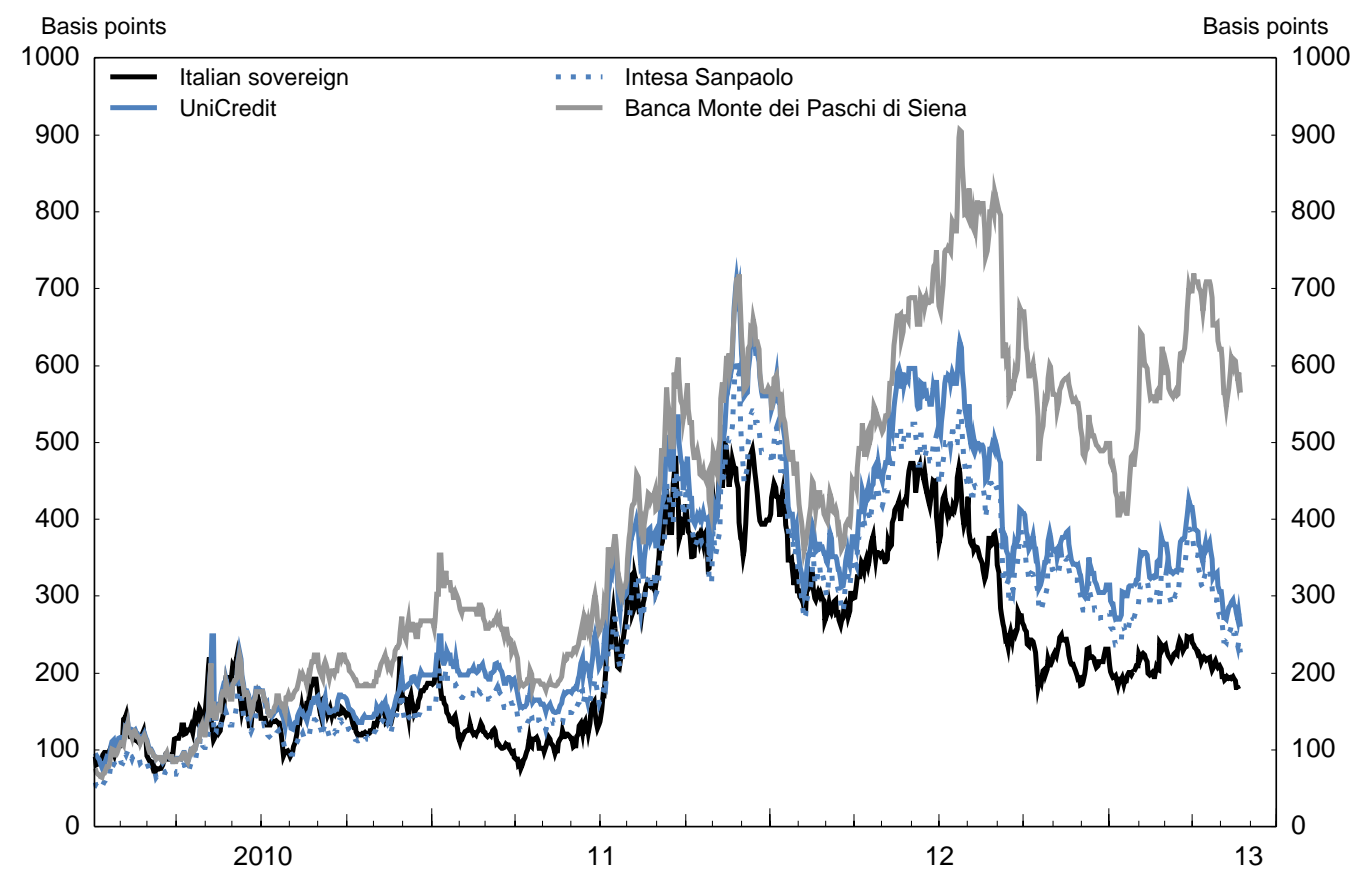

1. Senior 5 -year CDS premium (middle spread).

Source: Datastream. 
Investment by domestic banks in Italian government debt has significantly risen over the past four years. Since early 2009, domestic monetary financial institutions, excluding the Bank of Italy, have increased their holdings of general government debt from EUR 410 billion to EUR 630 billion, while other domestic financial institutions (such as insurance companies) saw their holdings rise from EUR 200 billion to EUR 350 billion; i.e. for domestic monetary and other financial institutions as a whole (excluding the central bank) holdings rose from some EUR 600 billion to almost EUR 1000 billion (Figure 11). Over the same period, domestic households and non-financial organisations as well as foreign investors have maintained similar amounts invested in Italian government debt, although since mid-2011 foreign investors have reduced their holdings, while those owned by domestic households and non-financial organisations have stayed unchanged. Hence, nearly all additional public debt accumulated since 2009 has been financed by domestic monetary and other financial institutions. The increase was particularly pronounced during the first half of 2012, a consequence of the 3-year long-term refinancing operations (LTROs) by the ECB.

Figure 11. Composition of general government gross debt by holders

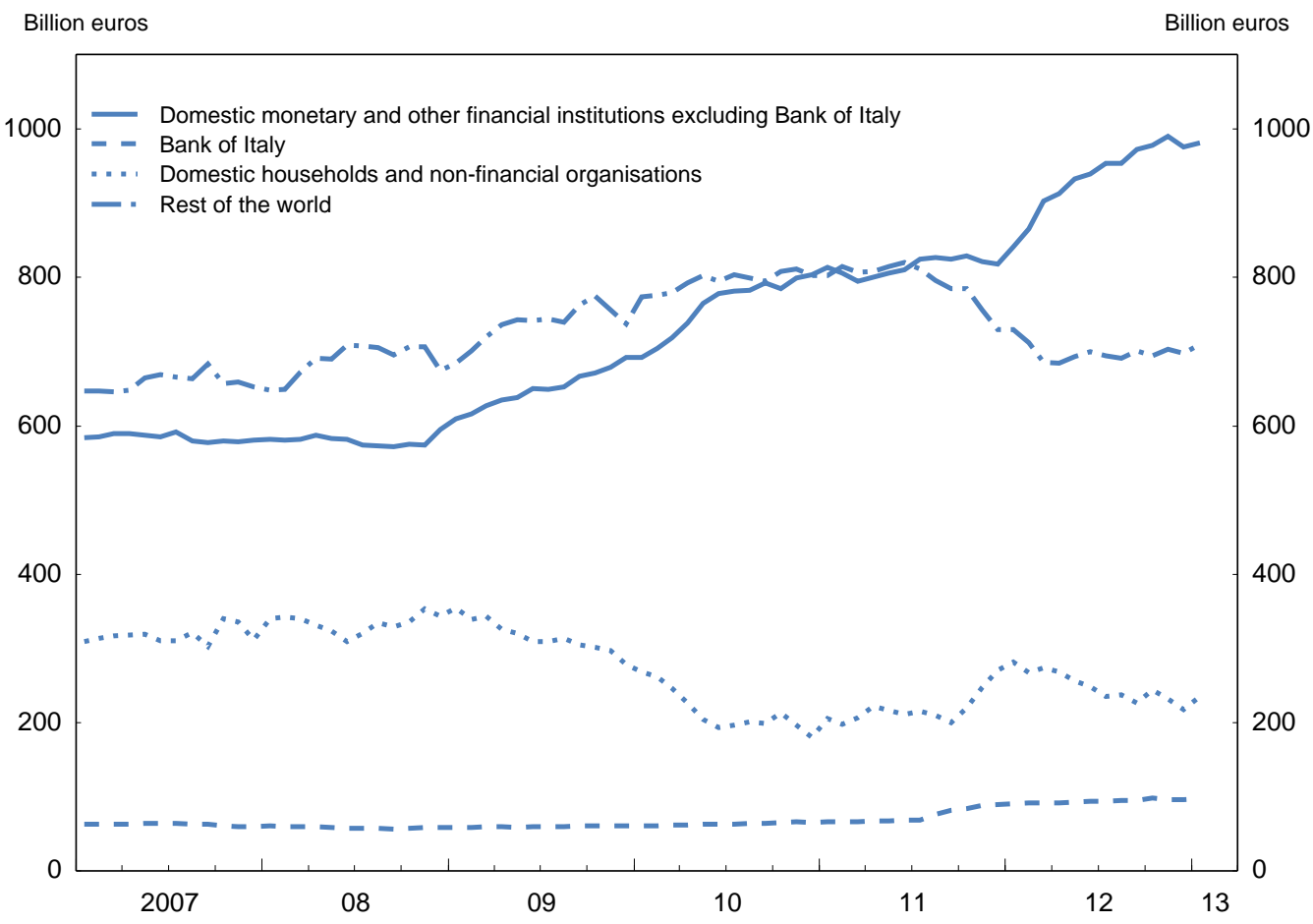

Source: Bank of Italy.

Exposure of banks to debt issued by the Italian Treasury is substantial in terms of their share in total risk-weighted assets and compared with banks' own capital. Calculations suggest that a small haircut, or fall in the market value, of $10 \%$ on Italy's public debt would reduce the Core Tier 1 capital ratio of the largest domestic banks by approximately $1-2 \frac{1}{2}$ percentage points; a haircut of $25 \%$ would lower it by $2-6 \frac{1}{2}$ percentage points (Figure 12). The numbers indicate how the lower prices on Italian government debt may have impacted Italian banks. With regard to the value of state guarantees, which the government provides either explicitly (through e.g. guaranteed bank bonds; see Grande et al., 2011, and Levy and Schich, 2010) or implicitly (through e.g. the possibility of bail-out), Schich and Lindh (2012) show that they significantly fell during 2010-12. As the situation of the sovereign has become more tenuous, the likelihood that the government would be able to provide support to ailing banks, should the need arise, has declined. 
Figure 12. Capital ratio simulations for Italy's top five banking groups

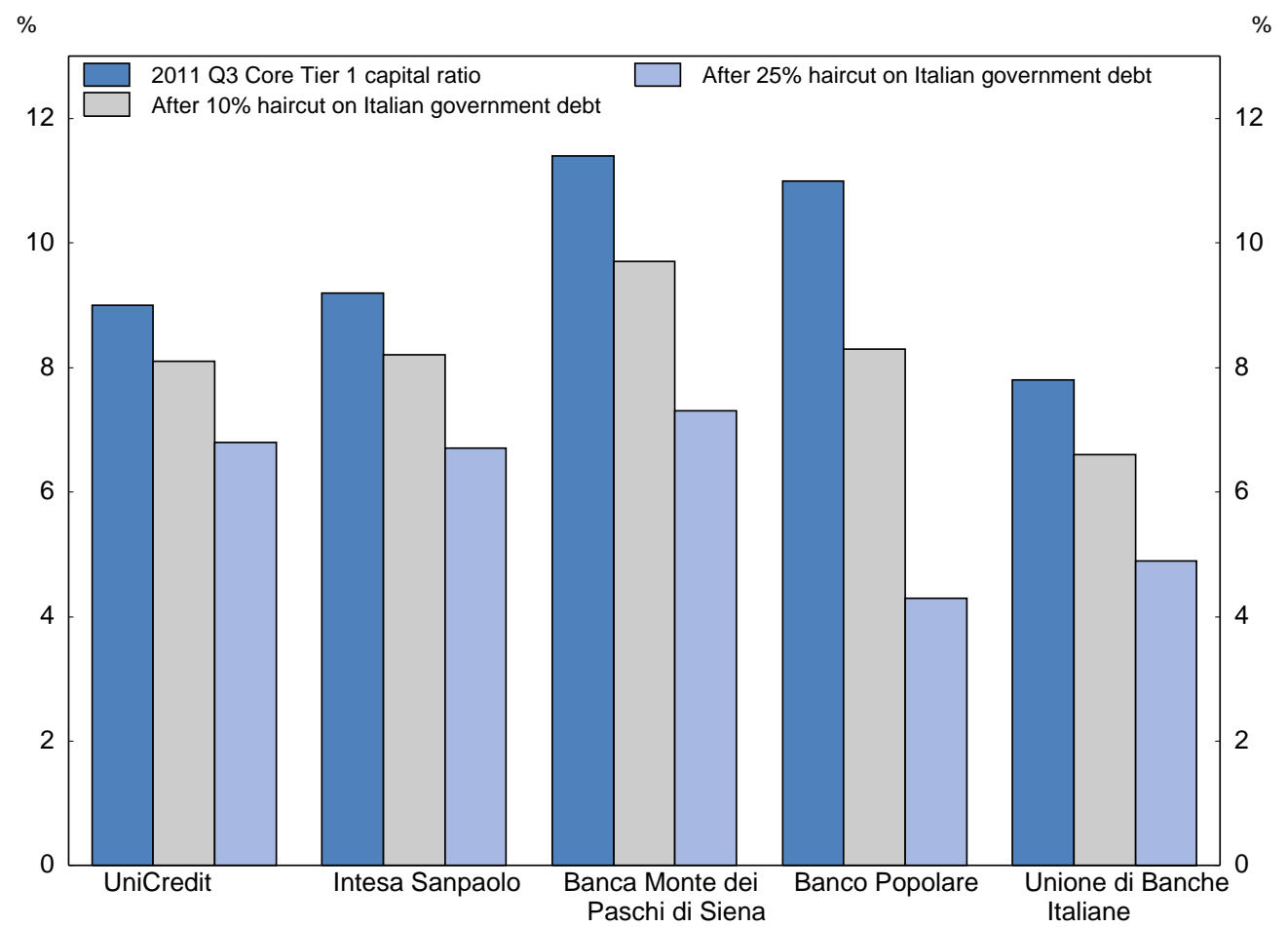

Source: OECD Secretariat estimates based on SNL European Banks Sovereign Exposure Template v1.

The problem of the link between the weak sovereign and weak banks could, in principle, be tackled by strengthening the capital positions of banks. Given the banks' difficulty in raising capital in the current environment, however, it is likely that the national government would have to provide some of the extra capital which would probably lead to an adverse reaction in financial markets. Thus, there is little Italy can do on its own to reduce the interdependence between its banks and public debt. Continuing the course of fiscal consolidation and growth-friendly structural reforms, together with firm supervision and regulation of the financial system, would help improve the respective strength of the banks and sovereign, thereby limiting the negative consequences arising from their interdependence.

A euro-area banking union would help break the bank-sovereign interaction in Italy, as in other countries. While the decision in June 2012 to create a common supervisory system for the euro area was a first step, followed up by a more detailed agreement in December, this is unlikely on its own to cut the feedback loop. A full banking union would have to add a common fiscal backstop together with a joint bank resolution regime and a joint deposit guarantee scheme to the already-decided single supervisory system. In the meantime, swift implementation of the decision on direct capital injection by the ESM into troubled banks would sever the links between the banks and the government. A euro-area banking union, plans for which Italy is providing support to, may have other implications, however. For example, a central regulator might not look favourably on banks maintaining disproportionate holdings of their national government debt. 


\section{The large-scale capital flight has stalled, though not significantly reversed}

Investor perceptions of the risk of a euro-area break-up, and also according to some observers anticipation of higher taxes, led to substantial capital outflows from Italy to the core countries of the euro area from mid-2011 to early 2012. The size of the capital flight can be gauged by the change in the TARGET2 balances with the ECB. TARGET2 balances represent the net position of each national central bank towards the ECB within the settlement system of the Eurosystem. Changes in TARGET2 liabilities are recorded in the capital account of the balance of payments. An increase in a country's TARGET2 liabilities can therefore principally arise for two reasons: a current account deficit (with the rest of the euro area) or a deficit on the capital account (with the rest of the euro area) that excludes changes in TARGET2 liabilities (e.g. Buiter et al., 2011).

Figure 13 plots the total level of TARGET2 claims for selected euro area countries over time. The increase in TARGET2 claims of the Bundesbank has been mirrored by the increase in TARGET2 liabilities of the national central banks in the peripheral countries. In Italy, TARGET2 liabilities, which were around zero until the summer of 2011, subsequently increased to EUR 290 billion in August 2012, the second highest in the euro area after Spain. The increase was particularly high from October 2011 to March 2012, during the period of the two LTROs.

Figure 13. Net claims of national central banks within the Eurosystem

TARGET2 balances

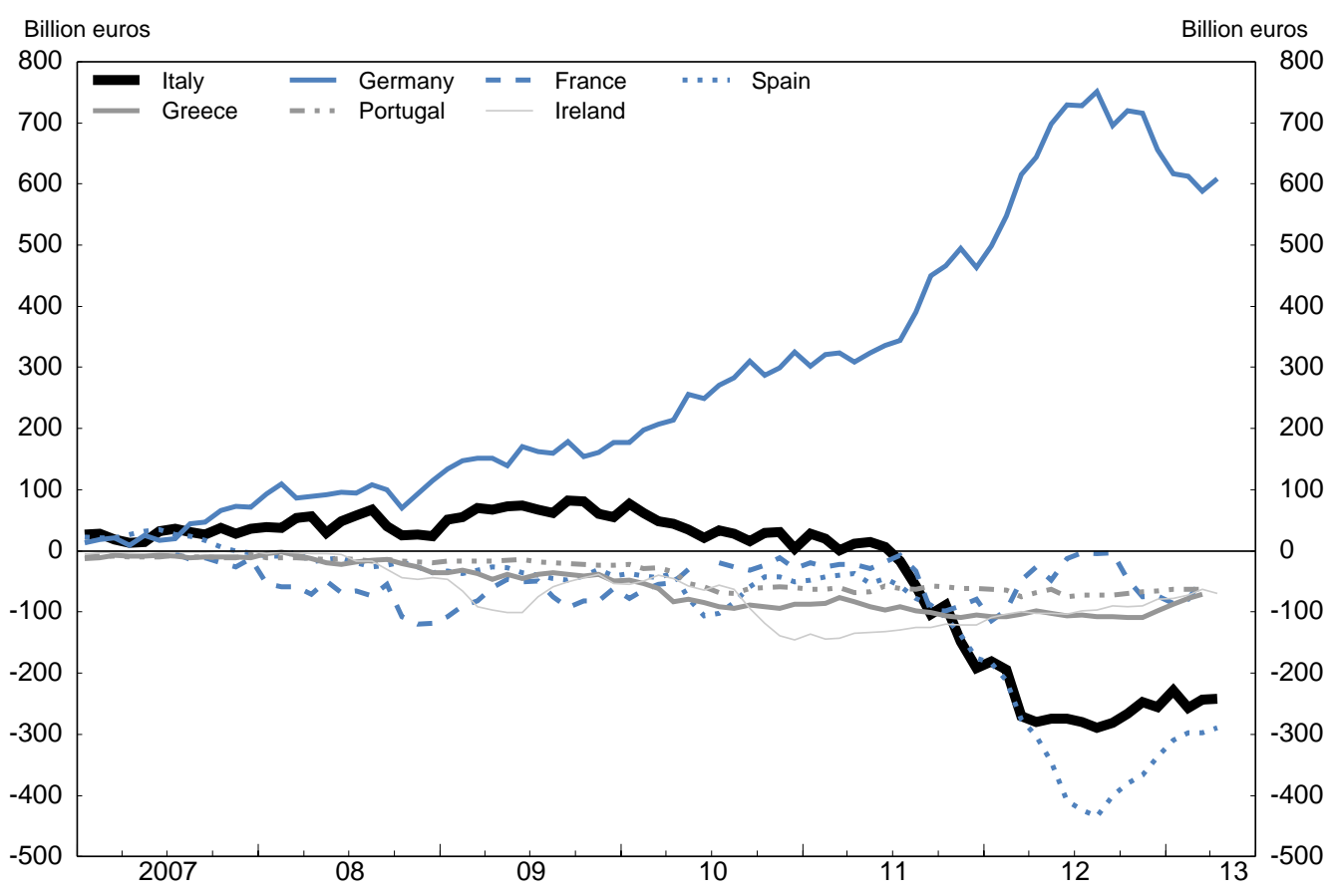

Source: Institute of Empirical Economic Research - Universität Osnabrück (www.eurocrisismonitor.uos.de).

Not all of the TARGET2 liabilities reflect capital movements; a proportion may be due to the current account deficit with the rest of the euro area. While those data are not available, current account data with the rest of the world, including the euro area, provide some indicative evidence. From the third quarter of 2011 to the second quarter of 2012, the aggregate current account deficit was only EUR 28 billion, suggesting that it is unlikely to explain most of the rise in TARGET2 liabilities. Using a detailed 
breakdown of balance of payments data, IMF (2012) estimates the capital outflows during this period to have been EUR 235 billion, approximately equal to 15\% of GDP. The capital drain stopped in mid-2012, perhaps in response to the ECB's efforts to reduce the perceived probability of a euro-area break-up, and about $15 \%$ of the initial outflows have since returned.

Capital flight is partly explained by foreigners withdrawing their deposits in Italian banks. The nominal amount of total deposits in Italy has remained broadly the same since mid-2011. However, whereas domestic deposits have increased over this period, foreign deposits have declined by more than $20 \%$ (Figure 14). They now account for only about $25 \%$ of Italy's deposit base, down from some $35 \%$ in 2007.

Figure 14. Domestic and foreign deposits

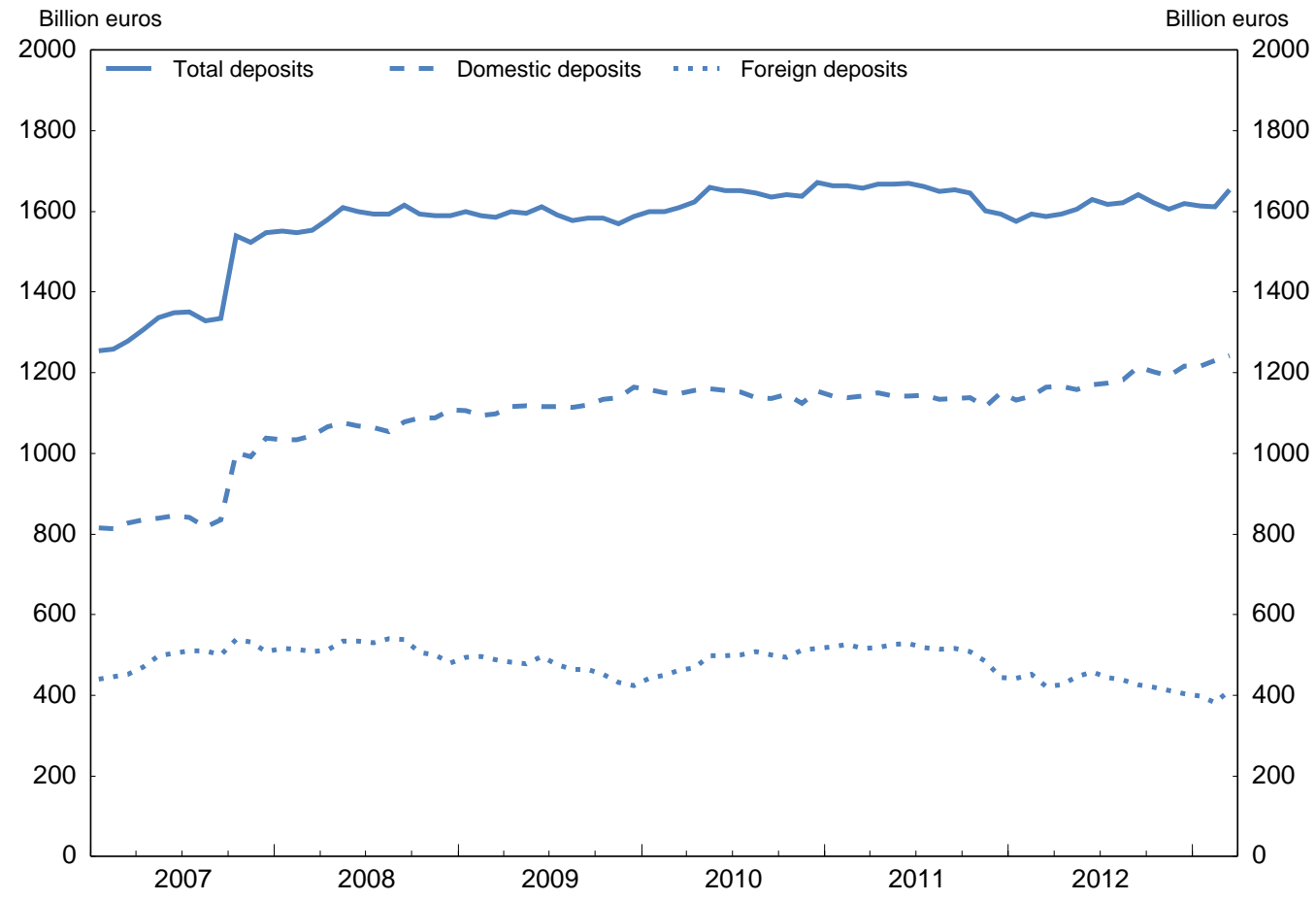

Source: Bank of Italy.

Capital flight is partly a result of some retrenchment within national borders in many European countries. It also reflects some pessimism about future prospects in Italy, however, reinforcing the importance of future governments in Italy continuing to improve fiscal sustainability, structural policies and financial stability. Euro-area wide measures to reduce the risk of Italy exiting the euro area are also necessary. The ECB's determined action in this regard since the summer of 2012, and the euro-area agreement on a single supervisory mechanism seem to have had some positive consequences for the evolution of Italy's TARGET2 liabilities and foreign deposits, whose balances have stabilised since.

\section{Lending growth to the private sector has been declining sharply}

The strains in the financial sector, caused by the weak situation of the economy and the public finances, as well as the tight liquidity conditions and higher capital requirements, have been limiting credit growth. Domestic banks' increased investments in Italian government bonds are likely to have raised the 
risk of crowding out some of the lending to the private sector. Due also to the fall in credit demand, yearon-year growth rates in bank lending to the non-financial private sector, both non-financial corporations and households, have fallen significantly since mid-2011 and in early 2013 were negative, and lower than at any time during the 2008-10 crisis (Figure 15, Panel A). The contraction in credit has paralleled the steep declines of investment.

Bank interest rates on lending to non-financial corporations and households have broadly mirrored the development of interest rates on government bonds, rising significantly from mid-2010 to early 2012 (Figure 15, Panel B). Since then they have eased somewhat, more so for large loans to non-financial corporations than for small loans to non-financial corporations and loans to households. Albertazzi et al. (2012) estimate that a 100 basis point increase in the sovereign spread produces, after one year, an increase of about 100 basis points in interest rates on loans to firms and 80 basis points in the rates for household mortgage loans.

Figure 15. Credit provision to firms and households
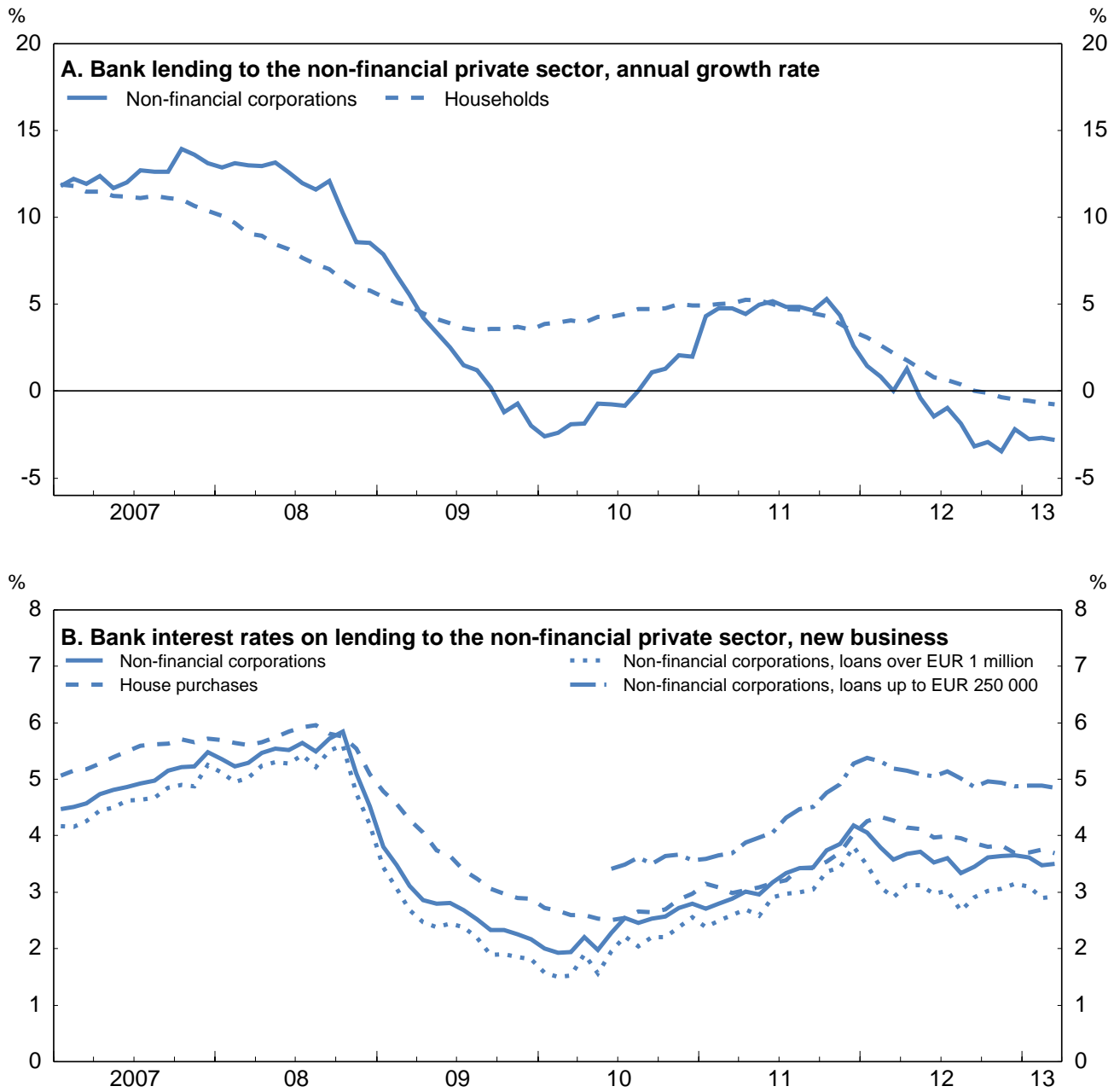

Source: Bank of Italy. 
Lower lending is the result of both flagging demand and tight supply. Demand by firms has been affected by the severe falls in investment and consumption since mid-2011, reflecting the unfavourable economic outlook and low confidence. In addition, reductions in inflationary expectations have raised real interest rates, hence have had an effect equivalent to monetary tightening (e.g. Eggertsson and Woodford, 2003). However, the rise of nominal bank interest rates indicates that deteriorating conditions in credit supply have played a major role, too. Supply conditions registered exceptional tensions in late 2011/early 2012, and continue to be restrictive. In the Bank of Italy's Bank Lending Survey conducted in early January 2013, banks related the tightening of supply to the poor economic situation and consequent increase in credit risk. Signals indicate that the difficulty of access to credit remained acute in the first few months of 2013: the percentage of firms reporting a tightening has been high, both according to the quarterly survey of the Bank of Italy-Il Sole 24 Ore and the monthly ISTAT survey.

Tight lending has especially affected small and medium-sized enterprises (SMEs). In the surveys by Confcommercio (2013), which have been conducted since 2008, the period since October 2011 has been the first time when more SMEs indicated that their loan applications were either refused or only partially accepted, rather than fully accepted. The impacts on SME lending have been significantly cushioned, however, by the Confidi, organisations providing banks with credit guarantees on behalf of their members, largely SMEs. The Confidi are supported by public institutions, trade associations and chambers of commerce. There are nearly 600 Confidi in all regions of Italy (Leone, 2012), and almost one million SMEs are members of a Confidi (OECD, 2013c). The Confidi play an important role in reducing asymmetric information between banks and enterprises. In doing so, they help SMEs to negotiate improved lending conditions (e.g. longer-term loans, lower interest rates, less collateral), compared with loans that each SME could obtain on the basis of its own securities only.

Less than $10 \%$ of all Confidi are currently under the supervision of the Bank of Italy. As a potential form of shadow banking, they need to be monitored. Indeed, strengthening their oversight is one of the G20/Financial Stability Board recommendations for Italy. A legislative framework from 2010 provides for a supervisory regime that divides the Confidi into two tiers according to the volume of their financial activity performed (the threshold is not set yet). "Larger" Confidi are subject to the same prudential measures as ordinary non-bank intermediaries, including authorisation by the Bank of Italy, while other Confidi are supposed to register with a self-regulatory body (the body is not set up yet) and to comply with a set of "lighter" rules. The Ministry of Economy and Finance needs to proceed with defining the threshold dividing the two tiers of Confidi and the operational and organisational aspects of the self-regulatory body. A general investigation of the efficiency of the Confidi system would be useful as, for example, by continuing to focus on providing collateral to banks, the Confidi may reduce banks' incentive to consider more innovative, project-based, financing to support innovation and growth in small firms.

\section{Banks need to make efforts to retain normal market funding}

The capital outflows and deterioration of wholesale funding conditions explain why over the past two years Italian banks have relied extensively on refinancing operations of the ECB. In the first half of 2012, for example, banks funded more than $6 \%$ of their assets by central bank borrowing, compared to just around $1 \%$ a year earlier. Corporations, both financial and non-financial, in the euro area are trying to match their assets and liabilities in each country to protect themselves against currency redenomination risks; this keeps liquidity from flowing from the core to the periphery, including Italy. Nonetheless, an expansion of ECB liquidity cannot be a permanent source of financing. The Italian authorities need to encourage banks to make efforts to retain normal market funding. Indeed, an increasing contribution has come from retail funding over the past year, although the contribution of wholesale funding continues to decline, as the resumption of their issuance in late 2012/early 2013 came to a halt with the uncertainty around the general election (Bank of Italy, 2013a, 2013b). 


\section{Banks should maintain high levels of capital}

Italian banks met the European Banking Authority's (EBA) target of 9\% of the Core Tier 1 capital ratio at end-June 2012. In December 2011, the EBA had asked four of Italy's top five banking groups (UniCredit, Banca Monte dei Paschi di Siena, Banco Popolare, Unione di Banche Italiane; Intesa Sanpaolo had no shortfall) to strengthen their capital positions. Of the four, only UniCredit, whose request by the EBA for additional capital was the second largest among all European banks (after Spain's Banco Santander), was able to raise fresh money from shareholders, though with some difficulties. Banco Popolare and Unione di Banche Italiane, rather than raising their capital, mainly shored up their balance sheets through the adoption of internal risk assessment models, authorised by the Bank of Italy, which implied a reduction in the calculation of the risk-weighted assets, not necessarily a sign of strength (Moody's, 2012).

Banca Monte dei Paschi di Siena (MPS), Italy's third largest banking group, required a capital injection by the government of EUR 2 billion to meet the EBA's target in June 2012, bringing the total lent to it by the Italian taxpayer to EUR 3.9 billion. If it is unable to pay the interest on these bonds, the state could become a stakeholder. MPS could not raise capital on its own, partly because of the reluctance of its existing shareholders, in particular the charitable foundation Monte dei Paschi, to accept a dilution of their stakes. In addition, subordinated debt holders effectively did not participate in the loss sharing (Box 1). Prior to receiving state aid, the Board of Directors was replaced, and a team from the Bank of Italy closely oversaw operations. Subsequently, in October 2012 Moody's cut the bank's rating to junk status, on the grounds that the bank might have to ask for still more public money, and in January 2013 MPS unveiled additional losses of EUR 220 million as a result of some previous derivative transactions.

\section{Box 1. The debt swap by Banca Monte dei Paschi di Siena in mid-2012}

On 27 June 2012, Banca Monte dei Paschi di Siena announced it would sell EUR 2 billion of special bonds to the Italian Treasury, thus bringing the total amount lent to it by the government to EUR 3.9 billion. In addition to the new EUR 2 billion loan, the bank asked for its EUR 1.9 billion in Tremonti bonds to be rolled over. On 6 July 2012, the bank announced that holders of EUR 831.8 million and GBP 139.7 million of subordinated debt agreed to a debt swap, where bondholders had been offered senior fixed-rate euro-denominated bonds due in 2015 in exchange for their subordinated ones. Notionally, the holders of these notes accepted a haircut, suggesting that they effectively participated in the loss sharing.

However, in net present value terms the exchange was actually favourable to the debt holders, taking into account that market value of this type of debt was already significantly lower than its nominal value. In fact, the debt swap meant that the holders of subordinated notes became senior creditors which were promised much higher interest rates, effectively compensating for the haircut within the 3-year maturity of the bonds. At the same time, the rollover of Tremonti bonds together with the new government equity injection of capital effectively meant that these claims are now protected by a larger equity cushion. Hence, holders of bank debt experienced effective market value gains in their claims as a result of the government intervention.

The case of MPS exemplifies the complexity of the task involved in banking supervision. As outlined in Bank of Italy (2013c), the national supervisor has undertaken a series of measures to guarantee the viability of the bank, yet it could not avert the significant problems that have been building up in the bank. Given the prevailing idiosyncratic and systemic financial sector risks, the Bank of Italy needs to continue to refine the efficiency of its supervisory approach.

The largest five Italian banks all passed the most recent stress tests of the EBA in July 2011. However, in other OECD countries medium- and small-sized banks have been among the most vulnerable institutions during the course of the financial crisis, for example the Landesbanken in Germany or cajas in Spain. While the Bank of Italy regularly undertakes several exercises to examine the soundness of Italy's 
banking system as a whole, little official information is available on the health status of individual banks (except the five largest ones). Supervisors should transparently communicate recommendations issued to banks, and conduct and publish stress tests for a larger set of banks than is currently done. Such a more comprehensive approach to banking supervision (which may require coordination on the European level) would help alleviate adverse selection problems among banks and investors, potentially promoting banks' access to capital through the retail and wholesale markets.

Although balance sheet ratios indicate that Italian banks are on average less leveraged than their European peers (OECD, 2012c), the banking sector will need more capital to meet regulatory requirements, to offset ongoing losses, and to support additional lending. The Italian authorities should thus encourage banks to meet their capital needs through raising equity from private sources, by retaining earnings or by disposing of non-core assets, rather than by restricting lending. The Bank of Italy has broadly followed this approach, for example by asking banks to frame their dividend and executive compensation policies to contribute to achieving the EBA's capital targets.

The ownership structure of many banks, including the largest ones, may constrain their ability to raise new capital. Important shareholders are banking foundations - local, private and not-for-profit organisations (including for tax purposes), supervised by the Ministry of Economy and Finance. Local communities are strongly represented in the governing bodies of the banks owned by banking foundations. The foundations, which rely on the income from their investments in banks to fund local projects, including social and cultural activities, have in the past, like Banca Monte dei Paschi di Siena, often been reluctant to accept a dilution of their voting rights. This may be a problem, as rating agencies attribute the relatively worse performance of some Italian banks to the observation that they are more beholden to foundation shareholders.

Encouraging competition in the financial sector is likely to improve banks' efficiency. There are some signs of inefficiency. For example, the degree of development across a range of financial products (including credit cards, asset management, life insurance, pension funds, mortgages) is lower in Italy than elsewhere in Europe. Also, the number of bank branches has risen over the last decade, despite the sharp increase in telephone and online banking services. As has previously been argued by the Governor of the Bank of Italy (Visco, 2012), Italian banks must rationalise their distribution networks by making more efficient use of information and communication technologies. One source of additional competition, and capital, might be from abroad, although this is likely to depend on a notable reduction in the market fragmentation in the euro area. In the past, there was some hostility to foreign ownership, and the authorities should ensure that excessive attachment to, for instance, the special position of the banking foundations and the Confidi does not hinder potential entrants into the sector.

An important interconnection between the value of banks and public debt is related to the too-big-tofail (TBTF) status. This reflects the perception that the government would be compelled to support failing banks if they are considered sufficiently large and interconnected to matter for the financial system as a whole and the real economy. Evidence (e.g. Schich and Kim, 2012) suggests that actual resolution practises matter for the perception of the TBTF status. Making failing institutions more easily resolvable and resolving institutions in distress is helpful in reducing these links. Italy has a modern special failure resolution regime for banks (for a brief summary see, for example, European Commission, 2009), and the regime was successfully used in a few high-profile cases in the 1990s.

The regime is designed so as to treat all banks, including those owned by banking foundations, as well as financial intermediaries like the Confidi, as if the identity of the owner, as opposed to the underlying capital and solvency and other fitness tests, was not important. In the case of a bank failure, other OECD countries have often avoided the bail-in of subordinated and senior unsecured debt holders. When banks are in distress, the Italian authorities should encourage the involvement of unsecured debt holders in the 
pre-insolvency loss sharing. Their consequent participation in case of failure resolution is part of the G20/Financial Stability Board recommendations. It would protect secured creditors, depositors and taxpayers, and ensure market discipline in the financial sector.

\section{Banks should be encouraged to adopt specific corporate structures}

Financial sector reform efforts present the opportunity to put the financial system on a more stable long-term footing by changing the organisation of banks. In particular, the Italian authorities should consider separating securities businesses from commercial and retail banking to address the TBTF issue by encouraging banks to adopt the non-operating holding company (NOHC) structure (OECD, 2009; Blundell-Wignall and Atkinson, 2012). In this, the parent is a non-operating holding company that raises equity which it invests in separate subsidiaries. The subsidiaries are divided (at a minimum) into: $i$ ) the retail bank which is a deposit-taking entity, to which deposit insurance and strong capital and liquidity rules apply; and ii) the securities businesses which face more limited regulation but have no deposit insurance. The subsidiaries are ring-fenced, so that the parent requires regulatory approval to shift capital and assets between them. While the retail bank's main activities are deposit-taking and lending to households and SMEs and hence its risks are mainly related to the domestic economy, the securities businesses act in global capital markets with highly interconnected counterparties, including the shadowbanking sector.

Adopting the NOHC structure would help further strengthen the structural resilience of Italy's banking system, although currently consolidation rules by the Bank of Italy already provide some protection against poor capitalisation of subsidiaries. The NOHC has the advantage of preventing the creditors of one subsidiary pursuing the creditors of others in case of failure, thereby eliminating contagion risk. It also removes the cross-subsidisation of investment banking via the implicit guarantees in the TBTF status. NOHCs have recently been put in place voluntarily in some OECD countries by holding company groups containing a bank. For example, Macquarie Group in Australia, which has a banking license, uses a listed non-operating parent, an operating banking arm, and an operating securities arm (with a large set of listed and unlisted securities businesses), and in the United States General Electric also uses a similar structure. 


\section{Box 2. Summary of recommendations to improve fiscal sustainability and financial stability}

\section{Fiscal sustainability:}

- Pursue efforts to halt and reverse the upward trend in the debt-to-GDP ratio. This could be achieved with a balanced budget or small fiscal surplus; while additional fiscal tightening would have transitory negative effects on output, it would be rewarded by faster debt reduction and thus lower the risk of renewed financial-market reactions.

- If macroeconomic conditions deteriorate once again, allow automatic stabilisers to work.

- Rebalance fiscal consolidation away from tax increases more towards spending control; spending cuts should be selective, and policy action needs to raise value-for-money.

- Implement the newly-legislated balanced-budget rule and fiscal framework with transparent data and methodology to allow effective monitoring of compliance.

- Establish the newly-legislated fiscal council, giving it full independence, well-qualified staff, perhaps reinforced by non-Italian members, guaranteed access to data, an adequate budget, and freedom to investigate as it judges necessary.

- Follow through on the pension reforms; greater use of training policies for older workers, in the context of a more general move to "flexicurity", and remuneration policies aligning wages with productivity through the lifecycle would help underpin the increase in the employment of older workers currently projected.

\section{Financial stability:}

- Ensure that banks further increase provisions against losses and that they recognise losses as they occur. To reduce the large stock of non-performing loans, speeding up foreclosure procedures should be an important objective of judicial reforms.

- Continue to urge banks to make efforts to retain normal market funding and to meet their capital needs by raising equity from private sources, including from foreign stakeholders, by retaining earnings and by disposing of noncore assets, rather than by restricting lending.

- Promote competition in the financial sector, e.g. through new entrants, including from abroad.

- Publish more detailed information on the health status of individual banks, and conduct stress tests for a larger set of banks than is currently being done.

- Use all bank failure instruments available for banks in distress, and encourage the involvement of unsecured debt holders in the pre-insolvency loss sharing.

- Encourage banks to adopt a non-operating holding company structure to separate securities businesses from commercial and retail banking, thereby addressing the too-big-to-fail issue. 


\section{BIBLIOGRAPHY}

Albertazzi, U., T. Ropele, G. Sene, and F. M. Signoretti (2012), “The Impact of the Sovereign Debt Crisis on the Activity of Italian Banks", Bank of Italy Occasional Papers, No. 133.

Alesina, A., C. Favero, and F. Giavazzi (2013), “The Output Effect of Fiscal Consolidations”, Working Paper.

Bank of Italy (2013a), Financial Stability Report, April 2013, Rome.

Bank of Italy (2013b), Economic Bulletin, April 2013, Rome.

Bank of Italy (2013c), Main Supervisory Activities with Regard to the Monte dei Paschi di Siena Group, January 2013, Rome.

Blundell-Wignall, A., and P. E. Atkinson (2012), "Deleveraging, Traditional versus Capital Markets Banking and the Urgent Need to Separate and Recapitalise G-SIFI Banks", OECD Journal: Financial Market Trends, 102.

Buiter, W. H., E. Rahbari, and J. Michels (2011), "The Implications of Intra-Euro Area Imbalances in Credit Flows", Centre for Economic Policy Research Policy Insights, No. 57.

Confcommercio (2013), Osservatorio sul Credito, March 2013, Rome.

Corsetti, G., K. Kuester, A. Meier, and G. J. Müller (2013), "Sovereign Risk, Fiscal Policy, and Macroeconomic Stability”, Economic Journal, 123(566), pp. F99-F132.

Di Cesare, A., G. Grande, M. Manna, and M. Taboga (2012), "Recent Estimates of Sovereign Risk Premia for Euro-Area Countries", Bank of Italy Occasional Papers, No. 128.

Égert, B. (2010), "Fiscal Policy Reaction to the Cycle in the OECD: Pro- or Counter-Cyclical?", OECD Economics Department Working Papers, No. 763.

Eggertsson, G. B., and M. Woodford (2003), "The Zero Bound on Interest Rates and Optimal Monetary Policy", Brookings Papers on Economic Activity, 34(1), pp. 139-235.

European Commission (2009), An EU Framework for Cross-Border Crisis Management in the Banking Sector, Brussels.

European Commission (2012), The 2012 Ageing Report: Economic and Budgetary Projections for the 27 EU Member States (2010-2060), Brussels.

Grande, G., A. Levy, F. Panetta, and A. Zaghini (2011), "Public Guarantees on Bank Bonds: Effectiveness and Distortions", OECD Journal: Financial Market Trends, 101.

Hagemann, R. (2010), "Improving Fiscal Performance through Fiscal Councils", OECD Economics Department Working Papers, No. 829.

IMF (2009), Fiscal Rules - Anchoring Expectations for Sustainable Public Finances, Washington DC.

IMF (2012), Global Financial Stability Report, October 2012, Washington DC. 
Laubach, T. (2009), "New Evidence on the Interest Rate Effects of Budget Deficits and Debt", Journal of the European Economic Association, 7(4), pp. 858-885.

Lenain, P., R. Hagemann, and D. Carey (2010), "Restoring Fiscal Sustainability in the United States", OECD Economics Department Working Papers, No. 806.

Leone, P. (2012), "The Guarantee System in Italy", in: Credit Guarantee Institutions and SME Finance, eds: P. Leone and G. A. Vento, Palgrave Macmillan, Basingstoke.

Levy, A., and S. Schich (2010), "The Design of Government Guarantees for Bank Bonds: Lessons from the Recent Financial Crisis", OECD Journal: Financial Market Trends, 98.

Mertens, K., and M. O. Ravn (2013), "The Dynamic Effects of Personal and Corporate Income Tax Changes in the United States", American Economic Review, forthcoming.

Moody’s (2012), Weekly Credit Outlook, 28 May 2012, New York.

OECD (2009), The Financial Crisis: Reform and Exit Strategies, OECD Publishing, Paris.

OECD (2011), Pensions at a Glance 2011: Retirement-Income Systems in OECD and G20 Countries, OECD Publishing, Paris.

OECD (2012a), OECD Pensions Outlook, OECD Publishing, Paris.

OECD (2012b), OECD Economic Outlook, May 2012, OECD Publishing, Paris.

OECD (2012c), OECD Economic Outlook, November 2012, OECD Publishing, Paris.

OECD (2013a), OECD Economic Outlook, May 2013, OECD Publishing, Paris.

OECD (2013b), OECD Economic Surveys: Italy, OECD Publishing, Paris.

OECD (2013c), SME and Entrepreneurship Financing: The Role of Credit Guarantee Schemes and Mutual Guarantee Societies in Supporting Finance for Small and Medium-Sized Enterprises, OECD Publishing, Paris.

Padoan, P. C., U. Sila, and P. van den Noord (2012), “Avoiding Debt Traps: Financial Backstops and Structural Reforms”, OECD Economics Department Working Papers, No. 976.

Schich, S., and B.-H. Kim (2012), "Developments in the Value of Implicit Guarantees for Bank Debt: The Role of Resolution Regimes and Practices", OECD Journal: Financial Market Trends, 103.

Schich, S., and S. Lindh (2012), “Implicit Guarantees for Bank Debt: Where Do We Stand?", OECD Journal: Financial Market Trends, 102.

Visco, I. (2012), Address at the $88^{\text {th }}$ World Savings Day, 31 October 2012, Rome. 
ECO/WKP(2013)51

\section{WORKING PAPERS}

The full series of Economics Department Working Papers can be consulted at www.oecd.org/eco/workingpapers/

1064. Policy implementation in Italy: legislation, public administration and the rule of law (June 2013) by Paul O’Brien

1063. Greening growth in Luxembourg

(June 2013) by Nicola Brandt

Vers une croissance plus verte en Luxembourg

(juin 2013) par Nicola Brandt

1062. The post-crisis narrowing of international imbalances - cyclical or durable?

(June 2013) by Patrice Ollivaud and Cyrille Schwellnus

1061. Restructuring welfare spending in Slovenia

(June 2013) by Rafał Kierzenkowski

1060. The economics of civil justice: new cross-country data and empirics

by G. Palumbo; G. Giupponi; L. Nunziata and J. Mora-Sanguinetti (forthcoming)

1059. Banks' restructuring and smooth deleveraging of the private sector in Slovenia

(June 2013) by Olena Havrylchyk

1058. Assessing the efficiency of welfare spending in Slovenia with data envelopment analysis (June 2013) by Matevz Hribernik and Rafał Kierzenkowski

1057. Policy determinants of school outcomes under model uncertainty: evidence from South Africa (June 2013) by Thomas Laurent, Fabrice Murtin, Geoff Barnard, Dean Janse van Rensburg, Vijay Reddy, George Frempong and Lolita Winnaar

1056. Improving education quality in South Africa

(June 2013) by Fabrice Murtin

1055. The 90\% public debt threshold: the rise and fall of a stylised fact

(June 2013) by Balázs Égert

1054. Challenges to sustain Poland's growth model

(June 2013) by Balázs Égert and Rafał Kierzenkowski

1053. Reforming agriculture and promoting Japan's integration in the world economy

(May 2013) by Randall S. Jones and Shingo Kimura

1052. Inequality and poverty in the United States: public policies for inclusive growth

(May 2013) by Oliver Denk, Robert Hagemann, Patrick Lenain and Valentin Somma

1051. Fiscal federalism and its impact on economic activity, public investment and the performance of educational systems

(May 2013) by Hansjörg Blöchliger, Balázs Égert and Kaja Fredriksen

1050. Restoring Japan's fiscal sustainability 
(May 2013) by Randall S. Jones and Satoshi Urasawa

1049. Measuring total factor productivity at the firm level using OECD-ORBIS

(May 2013) by Peter Gal

1048. A projection method for public health and long-term care expenditures

(June 2013) by Christine de la Maisonneuve and Joaquim Oliveira Martins

1047. R\&D, patenting and growth: the role of public policy

(May 2013) by Ben Westmore

1046. Knowledge-based capital, innovation and resource allocation

(May 2013) by Dan Andrews and Chiara Criscuolo

1045. Reforms for a Cleaner, Healthier Environment in China

(April 2013) by Sam Hill

1044. Making the tax system less distortive in Switzerland

(April 2013) by Andrés Fuentes

1043. The determinants of informality in Mexico's states

(April 2013) by Sean M. Dougherty and Octavio Escobar

1042. Legal reform, contract enforcement and firm size in Mexico (April 2013) by Sean M. Dougherty

1041. Improving the economic situation of young people in France

(April 2013) by Hervé Boulhol

Améliorer la situation économique des jeunes en France

(avril 2013) par Hervé Boulhol

1040. Improving employment prospects for young workers in Spain (April 2013) by Anita Wölfl

1039. Youth labour market performance in Spain and its determinants - a micro-level perspective (April 2013) by Juan J. Dolado, Marcel Jansen, Florentino Felgueroso, Andres Fuentes and Anita Wölfl

1038. The efficiency and equity of the tax and transfer system in France

(April 2013) by Balázs Égert

Efficacité et équité du système de prélèvements et de transferts en France

(avril 2013) par Balázs Égert

1037. Income inequality and poverty in Colombia. Part 2. The redistributive impact of taxes and transfers

(April 2013) by Isabelle Joumard and Juliana Londoño Vélez

1036. Income inequality and poverty in Colombia. Part 1. The role of the labour market (April 2013) by Isabelle Joumard and Juliana Londoño Vélez 